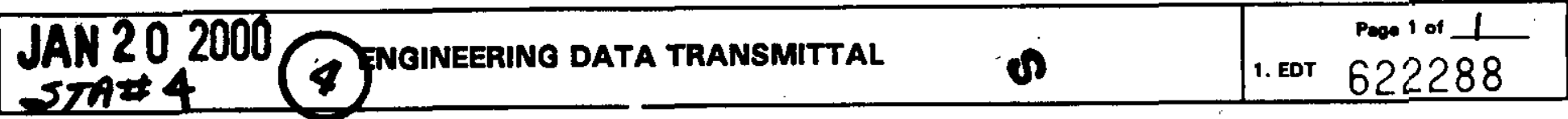

\begin{tabular}{|c|c|c|c|c|c|c|c|c|}
\hline \multicolumn{3}{|c|}{$\begin{array}{l}\text { 2. To: (Recelving Organization) } \\
\text { Distribution }\end{array}$} & \multicolumn{2}{|c|}{$\begin{array}{l}\text { 3. From: (Originating Organization) } \\
\text { M. V. Shultz, Fluor Federal } \\
\text { Services }\end{array}$} & \multicolumn{4}{|c|}{$\begin{array}{l}\text { A. Related EDT No.: } \\
\text { N/A }\end{array}$} \\
\hline \multicolumn{3}{|c|}{ 5. Proj.7Prog.7Dept./DIv.: } & \multicolumn{2}{|c|}{$\begin{array}{l}\text { 6. Design Authority/ Design } \\
\text { Agent/Cog. } \\
\text { Engr.: } \\
\text { L. A. Rodgers }\end{array}$} & \multicolumn{4}{|c|}{$\begin{array}{l}7 . \text { Purchase Order No: } \\
\qquad N / A\end{array}$} \\
\hline \multirow{2}{*}{\multicolumn{5}{|c|}{ 8. Originator Remarks: }} & \multicolumn{4}{|c|}{$\begin{array}{l}\text { 9. Equip./Component No.: } \\
\text { N/A }\end{array}$} \\
\hline & & & & & \multicolumn{4}{|c|}{$\begin{array}{l}\text { 10. System/BIdg./Fac1lity: } \\
\text { N/A }\end{array}$} \\
\hline \multirow{3}{*}{\multicolumn{3}{|c|}{ 11. Recelver Remarks: }} & \multirow{3}{*}{\multicolumn{2}{|c|}{ Basel1ne Document? [] Yes $[\mathrm{X}]$ No }} & \multicolumn{4}{|c|}{$\begin{array}{c}\text { 12. Major Assm. Dwg. No.: } \\
\text { N/A }\end{array}$} \\
\hline & & & & & \multicolumn{4}{|c|}{$\begin{array}{l}\text { 13. Permit/Permit Application } \\
\text { No.: } \\
\text { N/A }\end{array}$} \\
\hline & & & & & \multicolumn{4}{|c|}{$\begin{array}{c}\text { 14. Required Response Date: } \\
\text { N/A }\end{array}$} \\
\hline 15. & \multicolumn{4}{|c|}{ DATA TRANSMITTED } & (E) & (G) & (H) & (I) \\
\hline $\begin{array}{l}(\boldsymbol{X}) \\
\text { Itom } \\
\text { No. }\end{array}$ & 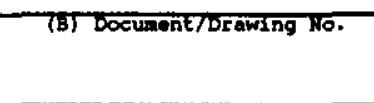 & $\begin{array}{c}\text { (c) } \\
\text { shoot } \\
\text { No. }\end{array}$ & Rov. & 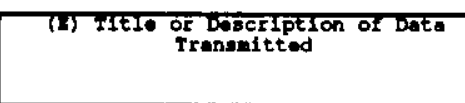 & $\begin{array}{l}\text { Approvar } \\
\text { Dosig- } \\
\text { nator }\end{array}$ & $\begin{array}{l}\text { Reason } \\
\text { for } \\
\text { Trans- } \\
\text { mittal }\end{array}$ & $\begin{array}{l}\text { Origi- } \\
\text { nator } \\
\text { Dispo- } \\
\text { sition }\end{array}$ & $\begin{array}{l}\text { Roceriv- } \\
\text { or } \\
\text { Dispo- } \\
\text { sition }\end{array}$ \\
\hline 1 & SNE-5569 & $\overline{\mathbf{N}} / \overline{\mathbf{A}}$ & 万 & $\begin{array}{l}\text { Probability of } \\
\text { Potential } \\
\text { Multicanister Over- } \\
\text { pack Loading Systems } \\
\text { Drop of Proof Load in } \\
\text { the } K \text { West Basin } \\
\text { South Loadout Pit }\end{array}$ & $\mathbf{S}$ & 1,2 & 1 & 1 \\
\hline & & & & & & & & \\
\hline
\end{tabular}

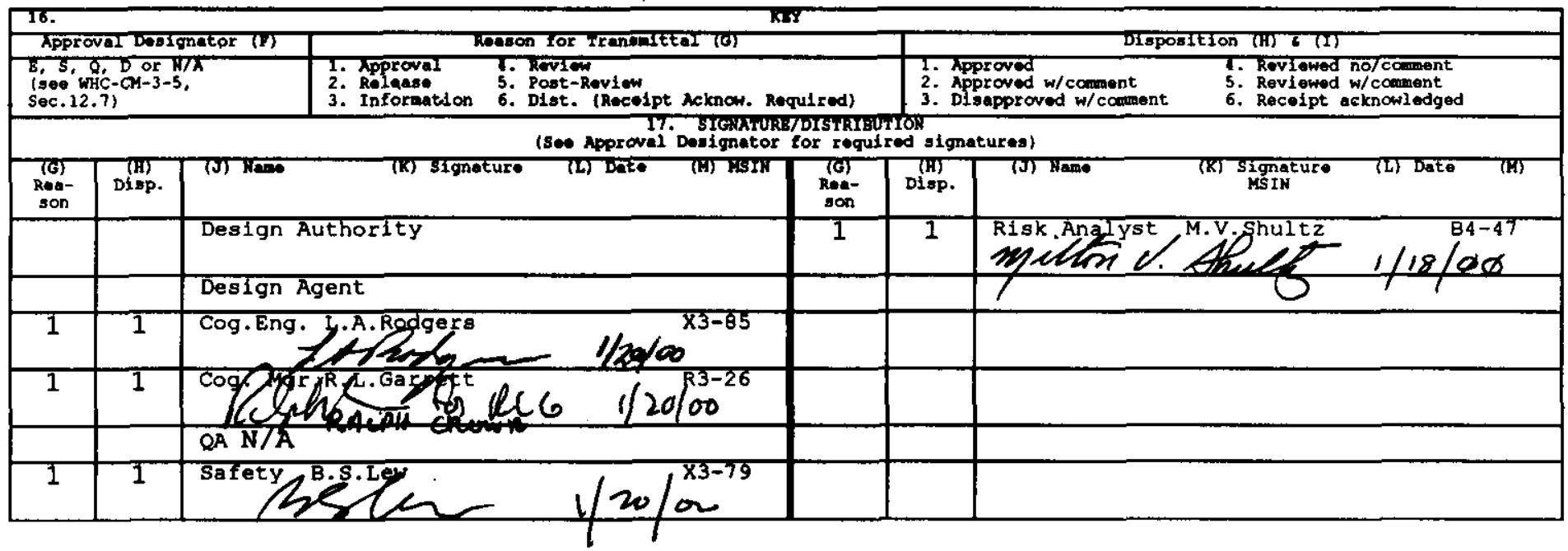

\begin{tabular}{|c|c|c|c|}
\hline 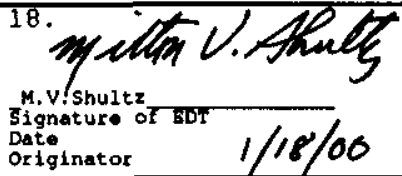 & 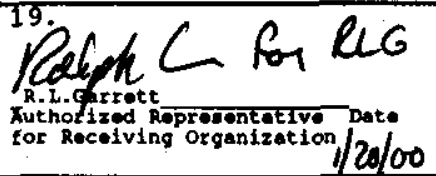 & 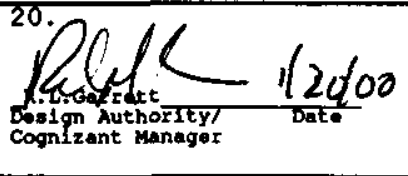 & $\begin{array}{l}\text { 21. DOE APPROVAL (if required) } \\
\text { Ctrl. No. } \\
\text { [] Approved } \\
\text { [] Approved w/Comments } \\
\text { [] Disapproved w/ comments }\end{array}$ \\
\hline
\end{tabular}

BD-7400-172-2 (05/96) GEF097 


\section{Probability of Potential Multi-Canister Overpack Loading System Drop of Proof Load in the K West Basin South Loadout Pit}

M. V. Shultz

Fluor Federal Services, Richland, WA 99352

U.S. Department of Energy Contract DE-AC06-96RL13200

$\begin{array}{ll}\text { EDT/ECN: } 622288 & \text { UC: } 620 \\ \text { Org Code: } 403 & \text { Charge Code: } 105350 / \text { CB80 } \\ \text { B\&R Code: }: \text { EW31300000 } & \text { Total Pages: } 43\end{array}$

Key Words: Spent nuclear fuel, crane drop, multi-canister overpack (MCO), load drop, K Basin, probability

Abstract: $\quad$ This document presents the results of a probabilistic analysis of the potential for load drop during the load test of the K West Basin South Loadout Pit Gantry. The calculations are in support of the cask loading system (CLS) subproject load test of the gantry.

TRADEMARK DISCLAIMER. Reference herein to any specific commercial product, process, or service by trade name, trademark, manufacturer, or otherwise, does not necessarily constitute or imply its endorsement, recommendation, or favoring by the United States Government or any agency thereof or its contractors or subcontractors.

Printed in the United States of America. To obtain copies of this document, contac Mailstop H6-08, Richland WA 99352, Phone (509) 372-2420; Fax (509) 376-4989.
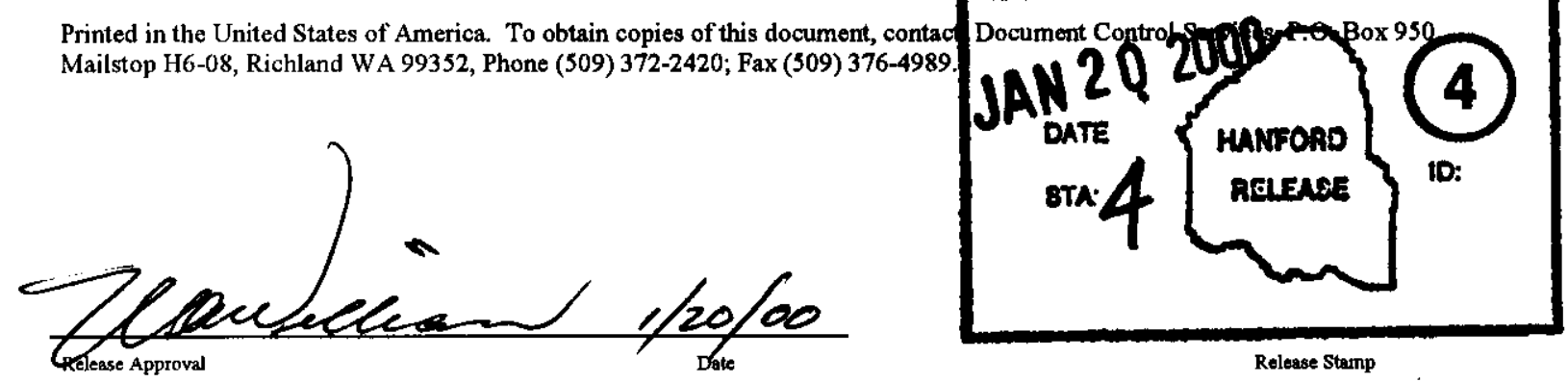

\section{Approved for Public Release}




\section{PROBABILITY OF POTENTIAL MULTI-CANISTER OVERPACK LOADING SYSTEM DROP OF PROOF LOAD IN THE K WEST BASIN SOUTH LOADOUT PIT}

M. V. Shultz, Jr.

Fluor Federal Service, Inc.

Richland, Washington

January 2000 
SNF-5569 REV 0

This page intentionally left blank. 


\section{CONTENTS}

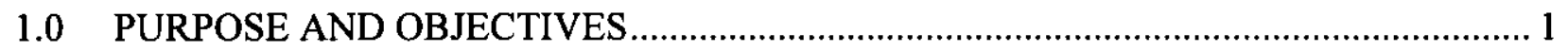

2.0 SUMMARY OF FINAL RESULTS AND CONCLUSIONS .................................... 1

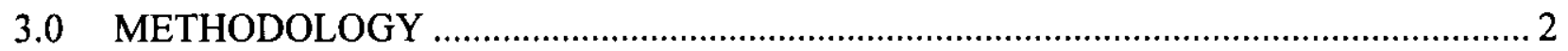

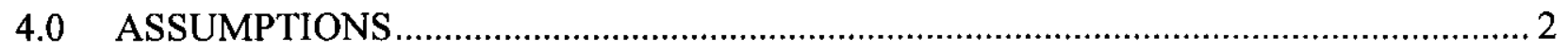

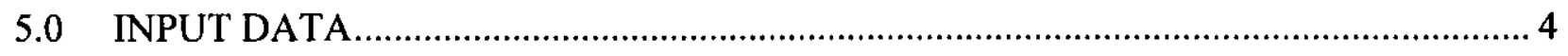

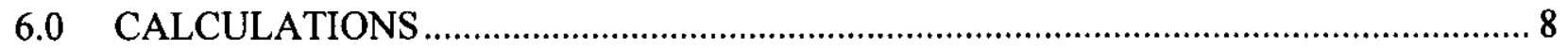

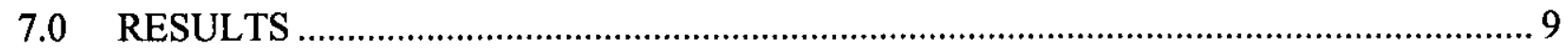

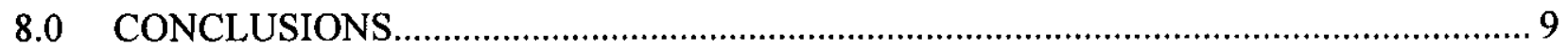

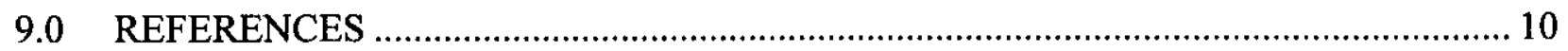

\section{LIST OF FIGURES}

1. Multi-Canister Loading System Load Drop in K West South Loadout Pit During Load Test

\section{APPENDICES}

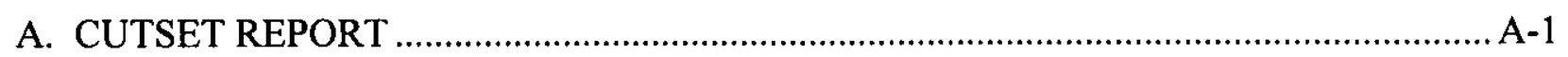

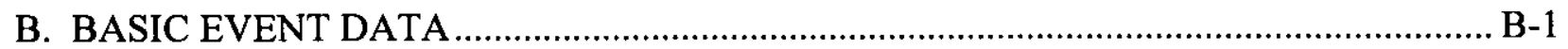

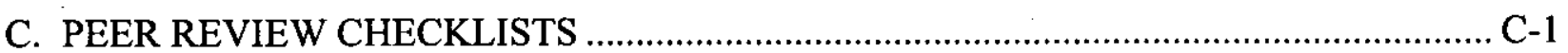


SNF-5569 REV 0

This page intentionally left blank. 


\section{LIST OF TERMS}

$\begin{array}{ll}\text { BHEP } & \text { basic human error probability } \\ \text { MCO } & \text { multi-canister overpack } \\ \text { MLS } & \text { MCO Loading System } \\ \text { PLC } & \text { Programmable Logic Controller } \\ \text { FRS } & \text { Fuel Recovery System } \\ \text { SAR } & \text { safety analysis report }\end{array}$


SNF-5569 REV 0

This page intentionally left blank. 
SNF-5569 REV 0

\section{PROBABILITY OF POTENTIAL MULTI-CANISTER OVERPACK LOADING SYSTEM PROOF LOAD DROP IN THE K WEST BASIN SOUTH LOADOUT PIT}

\subsection{PURPOSE AND OBJECTIVES}

The purpose of this calculation note is to document the probabilistic calculation of the per lift potential for drop of a test load by the Multi-Canister Overpack (MCO) Loading System (MLS) during load testing at the K West Basin south loadout pit. The MLS subproject needs to load test the MLS in the K West Basin south loadout pit. To perform this test, a basket mockup weighing approximately $4,500 \mathrm{lb}(125 \%$ of a fully loaded $\mathrm{MCO}$ basket accounting for water displacement) needs to be used for one or more load tests. The test load will comprise a standard basket lifting attachment with several ring-shaped steel segments to provide the required weight. The test load will exceed the $K$ Basin Safety Analysis Report (WHC-SD-WM-SAR-062) (SAR) allowances for load drop in the $\mathrm{K}$ West Basin south loadout pit. This probabilistic calculation will be used as part of the basis for seeking U.S. Department of Energy approval to use an MLS test weight that exceeds SAR allowances.

\subsection{SUMMARY OF FINAL RESULTS AND CONCLUSIONS}

The point estimate value calculated for the probability of potential MLS test load drop in the south loadout pit is $1.1 \times 10^{-6}$ per load test. A load test is defined as the lift by the MLS of the test load from the Fuel Recovery System (FRS) shuttle, movement of the test load to the MCO loading position, lowering of the test load into the $\mathrm{MCO}$, and reversal of this process with return of the test load to the FRS shuttle. The probability of $1.1 \times 10^{-6}$ per lift is approximately a factor of 25 smaller than the midpoint of the crane load drop failure data provided in NUREG-0612, Control of Heavy Loads at Nuclear Power Plants.

The dominant contributors to the load drop probability are the potential random failure of the MLS support structure, the MLS structure, and the grapple structure. The failure of the load locking rod lift cylinder air valve coupled with the failure of the locking rod locking pawl also has a similar probability of failure to the random structural failures.

The potential for external influences causing a load drop is also present. Basin crane impacts with the MLS and cask transport vehicle impacts with the MLS support structure during the load test need to be prevented. This can be accomplished with appropriate procedural controls and planning. 


\subsection{METHODOLOGY}

Fault tree analysis is used to calculate the probability of a potential MLS test load drop in the $\mathrm{K}$ West Basin south loadout pit. The fault tree logic represents the failures required before a potential drop by the MLS could occur in the K West Basin south loadout pit. The fault tree model is based on the physical layout detailed in NAC International, Inc. drawings 101 (sheets 1, 2, and 3), 201, 210, and 211. This information is also shown on Hanford drawing H-1-84031, Grapple Support Stand South Load-out Pit Plan and Details.

\subsection{ASSUMPTIONS}

The following assumptions were used in the development of the fault tree logic and failure probabilities used in this calculation note.

1. The basic human error probability (BHEP) used in the fault tree to represent an operator error is 0.03 . This value is documented in NUREG/CR-4772, Accident Sequence Evaluation Program Human Reliability Analysis Procedure (step 6 in Table 4-1, page 4-3).

2. The Programmable Logic Controller (PLC) that manages the operation of the MLS can fail in ways that would cause a load drop.

3. A single failure of the MLS support structure, MLS structure, lifting screw, or lifting grapple will result in a drop of the test load.

4. The test load will not spuriously disassemble based on the interlocking ring configuration of the steel weight segments.

5. The probability of test load hangup in the MCO during testing is negligible based on the fact that the test load is $2 \mathrm{in}$. smaller in diameter than a standard MCO fuel basket. However, test load hangup is assumed to be credible if the MLS is moved while the test load is being lifted from the MCO.

6. MLS structure failure probability due to material defect and/or fatigue is assumed to be $1.0 \times 10^{-7}$ per lift. Navy crane failure data from NUREG-0612 indicate a low-end failure probability per lift of $2.5 \times 10^{-5}$ (NUREG-0612, page 4-3). NUREG-0612 also indicates that, for non-inspected components with design factors of two, the probability of failure can be reduced by a factor of 0.1 . If the design factor is four (not atypical for load carrying equipment), then the probability of failure could be reduced by a factor of 0.01 . This would yield a failure probability of $2.5 \times 10^{-7}$ per lift. Since the equipment is newly manufactured and tested, the value was reduced to $1.0 \times 10^{-7}$ per lift. 
7. MLS support structure (structure permanently located in the south loadout pit area) failure probability due to material defect and/or fatigue is $1.0 \times 10^{-7} \mathrm{per}$ lift. This assumption is based on the reasons listed in assumption 6 .

8. MLS grapple structure failure probability due to material defect and/or fatigue is $1.0 \times 10^{-7}$ per lift. This assumption is based on the reasons listed in assumption 6 .

9. Loss of electrical power is not considered a significant initiator because the control system and design of the MLS are fail-safe under loss of power.

10. The MLS mast servo motor resolver, limit switches, and brake are tested just before the start of the load testing.

11. The MLS and grapple assembly have been tested to $150 \%$ of design capacity by the company that constructed the equipment before installation at the $\mathrm{K}$ West Basin. This testing provides assurance that the system is capable of performing the $125 \%$ load test, which would leave only random structural and operational failures as initiators of a test load drop.

12. "Free wheeling" of the MLS mast screw ball nut, when the test load is latched to the MLS grapple, can produce drop velocities sufficient to cause significant damage to the south loadout pit.

13. "Free wheeling" of the MLS mast screw ball nut is not credible unless the drive motor is decoupled from the mast screw ball nut.

14. The MLS grapple will not disengage from the test load unless air pressure is applied to the grapple air cylinder, the manual unlatching bail is actuated, or the grapple suffers a catastrophic structural failure.

15. Partial grapple lock ball engagement that would allow lifting the test load and creating the potential for a subsequent load drop has such a low probability that it does not have to be considered. Visual evidence is available through a slot in the grapple structure where the lock rod can be observed to verify that the lock rod has slid into the fully engaged position before a load is lifted.

16. A single load test will take $2 \mathrm{~h}$ to perform. A load test is defined as the lift by the MLS of the test load from the FRS shuttle, movement of the test load to the MCO loading position, lowering of the test load into the $\mathrm{MCO}$, and reversal of this process with return of the test load to the FRS shuttle.

17. Correct calibration of the horizontal motion hard stops has occurred before this test takes place. This validates the assumption that the positioning of the MLS for load pickup from the shuttle and lowering into the $\mathrm{MCO}$ is sufficiently accurate to prevent inadvertent hooking of the grapple manual unlatching bail unless other failures occur. 


\subsection{INPUT DATA}

This section describes the failure data used in the fault tree logic, that is described in Section 6.0, "Calculations," and presented graphically in Figure 1.

Event AIRVLVF is a failure of a solenoid air valve to operate on demand. The failure probability for the ball nut brake air release valve (brake is designed to be engaged when air pressure is removed) is assumed to be represented by the failure probability of a solenoid valve to open on demand, which is $3.0 \times 10^{-3}$ per demand (DP-1633, page 38).

Event AIRVALVF is a spurious failure of the locking pin air cylinder air valve that causes the lift side of the air cylinder to become pressurized. This results in the withdrawal of the locking rod if it is not restrained and a subsequent drop of the test load. The failure rate of a solenoid valve to spuriously operate is given as $5.0 \times 10^{-7} / \mathrm{h}$ (WSRC-TR-93-262, page 20). The test duration is assumed to be $2 \mathrm{~h}$.

Event BAILHOOK is the probability of the grapple manual unlocking bail hanging up on a projection in the south loadout pit when the test load is lowered in a location other than over the FRS shuttle or the MCO. The conditional probability is set to 1.0. This event is modeled to allow evaluation of the fact that unintentional operation of the manual load release may not be a certainty for every mispositioned load condition.

Event BELTFAIL is the failure of the ball nut drive belt. The Reliability Analysis Center of the U.S. Department of Defense in publication NPRD-95, Nonelectronic Parts Reliability Data 1990, indicates that drive belt failures occur at a rate of $3.88 \times 10^{-6} / \mathrm{h}$. The test duration is assumed to be $2 \mathrm{~h}$.

Event BRAKCFAL is a failure of the mechanical ball nut brake to operate on demand. Brake failure data from the Savannah River failure data compilation (DP-1633, page 11) range from $4.0 \times 10^{-6} / \mathrm{h}$ to $1.0 \times 10^{-5} / \mathrm{h}$. Conservatively assuming $10,000 \mathrm{~h} / \mathrm{yr}$, the brake would fail with an upper probability of $\left(1.0 \times 10^{-5} \mathrm{~h}\right)(10,000 \mathrm{~h})=1.0 \times 10^{-1}$. Assuming the brakes were applied 100 times per year, the demand failure would be $1.0 \times 10^{-1}$ per 100 demands, or $1.0 \times 10^{-3}$ per demand. This value compares well with the solenoid brake failure probability on demand (DP-1633, page 38), so $1.0 \times 10^{-3}$ is used to represent the failure probability of the mechanical ball nut brake per demand.

Event BRSENFAL is the failure of the ball nut drive belt tensioning transducer given that a drive belt failure has occurred. The failure rate for the drive belt tensioning transducer is assumed to be represented by the failure rate of position sensors. NPRD-95 indicates that position transducer failure occurs at a rate of $1.54 \times 10^{-5} / \mathrm{h}$. The test duration is assumed to be $2 \mathrm{~h}$.

Events GANTSTRU, GRAPSTRU, and SUPSTRUC are failures of the MLS structure, grapple structure, and MLS support structure, respectively. These are mechanical component failures. Navy crane failure data from NUREG-0612 indicate a low-end failure probability per 
lift of $2.5 \times 10^{-5}$ per lift (NUREG-0612, page 4-3). NUREG-0612 also indicates that, for noninspected components with design factors of two, the probability of failure can be reduced by a factor of 0.1 . If the design factor is four (not atypical for load carrying equipment), then the probability of failure could be reduced by a factor of 0.01 . This would yield a failure probability of $2.5 \times 10^{-7}$ per lift. Since the equipment is newly manufactured and tested, the value was reduced to $1.0 \times 10^{-7}$ per lift. The load test will consist of several lifting and lowering actions, but the MLS will not be unloaded until the test weight is returned to the FRS shuttle. Therefore, one lift per load test is defined as having occurred.

Events LCFAIL1, LCFAIL2, and LCFAIL3 are the random failure of the MLS load cells given a load hang-up has occurred. A failure of any one of the load cells is assumed to prevent the PLC from shutting down the ball nut drive motor from an overload condition. NPRD-95 indicates that strain gauge load transducer failure occurs at a rate of $1.2 \times 10^{-5} / \mathrm{h}$. The test duration is assumed to be $2 \mathrm{~h}$.

Event LOADHANG is a random PLC error that leads to hang-up of the test load while being lifted out of the MCO. The PLC is postulated to spuriously initiate horizontal movement of the MLS at the same time that the test load is being lifted out of the MCO. A PLC failure is assumed to be equivalent to microcircuit failure (INSPEC 1981, page 92), which has a failure rate of $\sim 1.0 \times 10^{-8} / \mathrm{h}$. The test duration is assumed to be $2 \mathrm{~h}$.

Event LSCOMMON is included in the fault tree model to account for common cause (or mode) failures of the mast full-up limit switches. The approach used is the beta factor method (NUREG CR-2300, page 3-90). In this method, the beta factor is multiplied by the failure rate of the redundant component to provide an estimate of the common cause failure rate. Beta factors normally range between 0.01 and 0.1 . A beta factor of 0.1 was chosen as a conservative screening value. The probability of a limit switch failing to open or close on demand is $3.0 \times 10^{-5}$ per demand based on EGG-SSRE-8875, Generic Component Failure Data Base for Light Water and Liquid Sodium Reactor PRAs (page 22). The failure rate for event LSCOMMON is therefore $3.0 \times 10^{-6}$ per demand.

Events LS1FAIL and LS2FAIL are the independent random failures of the MLS mast limit switches to stop upward movement of the mast before the grapple attachment structure "hard stops." This is assumed to result in failure of the screw attachment to the grapple and a subsequent drop of the test load. Since the limit switches are assumed to be tested before the load test, the failure of these limit switches over time will be detected before the test lift is performed. Thus the dominant failure mode of the limit switch is a failure to open or close on demand. The probability of a limit switch failing to open or close on demand is $3.0 \times 10^{-5}$ per demand based on EGG-SSRE-8875, Generic Component Failure Data Base for Light Water and Liquid Sodium Reactor PRAs (page 22).

Event MSHUTOFF is an operator error that leads to failure to recognize mispositioning of crane and actuate manual shutdown when PLC failure causes the test load to be lowered in an incorrect location. As indicated in Section 4.0, "Assumptions," the BHEP used for operator error is 0.03 . 
Event OPFAIL is the failure of the operator to recognize that the MLS has stopped at a position that does not line up with the MCO or the FRS shuttle and manually requests the PLC to lower the test load. As indicated in Section 4.0, "Assumptions," the BHEP used for operator error is 0.03 .

Event PLCFAIL0 is the random failure of the PLC to respond to an overload signal from a load transducer given that an overload condition exists. A PLC failure is assumed to be equivalent to microcircuit failure (INSPEC 1981, page 92), which has a failure rate of $\sim 1.0 \times 10^{-8} / \mathrm{h}$. The test duration is assumed to be $2 \mathrm{~h}$.

Event PLCFAIL2 is the random failure of the PLC that causes the controller to actuate the locking rod air piston to withdraw the locking rod, resulting in unlatching and dropping the test load. A PLC failure is assumed to be equivalent to microcircuit failure (INSPEC 1981, page 92), which has a failure rate of about $1.0 \times 10^{-8} / \mathrm{h}$. The test duration is assumed to be $2 \mathrm{~h}$.

Event PLCFAIL3 is the random failure of the PLC that causes the MLS mast to be driven to the up position "hard stop" point, resulting in a lift screw failure and subsequent load drop. Included in this event is failure to correctly calculate the position from the resolver input and failure to shut down the drive motor when the position is correctly calculated. A PLC failure is assumed to be equivalent to microcircuit failure (INSPEC 1981, page 92), which has a failure rate of $\sim 1.0 \times 10^{-8} / \mathrm{h}$. The test duration is assumed to be $2 \mathrm{~h}$.

Event PLCFAIL4 is the random failure of the PLC that results in the horizontal positioning of the MLS in an incorrect position to lower a basket to the FRS shuttle or MCO. A PLC failure is assumed to be equivalent to microcircuit failure (INSPEC 1981, page 92), which has a failure rate of $\sim 1.0 \times 10^{-8} / \mathrm{h}$. The test duration is assumed to be $2 \mathrm{~h}$.

Event PLCFAIL5 is the random failure of the PLC that results in the PLC spuriously lowering the test load before it is in position over the FRS shuttle or MCO. A PLC failure is assumed to be equivalent to microcircuit failure (INSPEC 1981, page 92), which has a failure rate of $\sim 1.0 \times 10^{-8} / \mathrm{h}$. The test duration is assumed to be $2 \mathrm{~h}$.

Event PLCFAIL8 is the random failure of the PLC to respond to a ball nut drive belt failure signal from the belt tensioning transducer given that a drive belt failure has occurred. A PLC failure is assumed to be equivalent to microcircuit failure (INSPEC 1981, page 92), which has a failure rate of $\sim 1.0 \times 10^{-8} / \mathrm{h}$. The test duration is assumed to be $2 \mathrm{~h}$.

Event RESOFAIL is the failure of the servo motor resolver to provide accurate position information to the PLC, which results in the MLS mast "hard stopping" as it is moved to the up position. This is assumed to result in failure of the screw attachment to the grapple and the subsequent drop of the test load. NPRD-95 indicates that resolver failure occurs at a rate of $1.14 \times 10^{-7} / \mathrm{h}$. The test duration is assumed to be $2 \mathrm{~h}$.

Event RODLOCKF is the failure of the load locking pin locking pawls to prevent the withdrawal of the locking pin when the locking pin air cylinder or manual unlocking bail are inadvertently actuated. The capability of the locking pawls to prevent the air cylinder from 
lifting the load locking pin has been verified by factory testing. "Estimating the Exponential Failure Rate from Data with No Failure Events" (Welker and Lipow 1974) provides a basis for estimating a failure rate based on data showing no failures. Using this technique, a failure rate of 0.1 could be obtained with as little as four tests with no failures. A failure rate of 0.1 per demand is applied to this event based on the assumption that several pawl tests have been performed successfully.

Event SCRWMATF is the failure of the MLS mast lift screw due to material defect or design error. NPRD-95 indicates that automotive axle failure occurs at a rate of $1.6 \times 10^{-8} / \mathrm{h}$. Although the lift screw is not identical to an automotive axle, the characteristics of an automotive axle operating under conditions of shock loading and varying stresses make it a good candidate to represent the failure characteristics of the lift screw. The test duration is assumed to be $2 \mathrm{~h}$.

Event SETPOINT is the failure of the operator to set the overload setpoint to the correct value, which allows an overload condition to cause a test load drop. As indicated in the Section 4.0, "Assumptions," the BHEP used for operator error is 0.03 . The BHEP is multiplied by an additional 0.01 to take credit for procedural steps that require a work package be developed to reset the load cell setpoints and a requirement to get a key from the shift manager for access to the controller to execute the work package. Thus the probability of event SETPOINT is $3.0 \times 10^{-4}$.

Events XPERROR1, XPERROR2, XPERROR3, AND XPERROR4 are included in the model to account for external events that may result in test load drop. These events are important because appropriate procedural controls need to be implemented to ensure that they do not dominate the drop probability.

- XPERROR 1 is the movement of the basin crane to a position that interferes with the MLS during the load test. This event is assumed to be composed of an error in planning that allows the basin crane to be operated and a failure in the planning review process to identify the fact that the crane should not be operated in the south loadout pit area during the MLS load test. A probability of 0.03 is assigned to the planning error, and a probability of $1 \times 10^{-2}$ is assigned to the failure of the review process to identify the error resulting a composite probability of $3 \times 10^{-4}$.

- XPERROR2 is the failure of personnel operating the basin crane to observe the potential for impact with the MLS and abort the operation. A probability of $1 \times 10^{-3}$ is assigned to this failure. These probabilities are consistent with human error probabilities used for scoping purposes.

- XPERROR3 is the unplanned movement of a parked cask truck during the load test due to human error and is assigned a probability of 0.03 .

- XPERROR4 is the probability that the truck strikes the MLS while load testing is being performed and causes a load drop. A probability of $1 \times 10^{-5}$ is assigned based on the considerations of size of the vehicle, impediments preventing the vehicle from 
striking the MLS, and the velocity needed to overcome the impediments in order to strike the MLS.

To reiterate, these events are included in the model to highlight the need for appropriate controls to prevent external influences from being a major factor in causing a test load drop.

Many of the assumptions in this fault tree model are very conservative. The following list details some of the conservative assumptions along with a statement of the more likely condition for each situation addressed.

- A test load drop event that can occur due to failure of the ball nut drive belt would require the ball nut to reach a very high rate of rotation. Actually, the ball nut would limit the velocity of the drop to a much lower value than what occurs from free fall.

- A "hard stop" condition would result in failure of the lift screw and a subsequent drop of the test load. Actually, the most likely result of a hard stop would be a burned out servo motor or a slipping belt that would be noticed by the operator.

- The operator would neglect recovery actions. Actually, the operator monitors the operation very closely. In addition, the MLS load test will be monitored by several other individuals who can provide input to the operator should failures occur.

\subsection{CALCULATIONS}

The logic to calculate the probability of a drop per lift is modeled as a fault tree in Figure 1. The solution of the fault tree in Figure 1 yields a list of minimal cutsets based on Boolean logic. A minimal cutset is the minimum number of failure events that will result in the top event. The failure probabilities discussed in Section 5.0, "Input Data," were used to quantify the solution of the fault tree in Figure 1. The computer software code CAFTA, version 2.1, was used to yield the minimal cutsets and quantify the top event of the fault tree in Figure 1. CAFTA, version 2.1, has been validated as reported in WHC-SD-MP-SWD-0004, CAFTA Computer Program Testing and Acceptance Report, and the results generated for this calculation note have been randomly spot checked by the technical reviewer to ensure the calculations were performed correctly. Appendix A is a listing of the minimal cutsets and their quantification for logic in Figure 1 using the input data discussed above. Appendix B shows the failure probability data base.

As an example, the quantification calculation for the following set of failures (cutset) that lead to a load drop involves the multiplication of the probabilities. If the events are defined as EVENT1, EVENT 2, and EVENT3 and their probabilities are $1.0 \times 10^{-2}, 1.0 \times 10^{-4}$, and $3.0 \times 10^{-2}$, respectively:

$$
\left(1.0 \times 10^{-2}[\text { EVENT1] })\left(1.0 \times 10^{-4}[\text { EVENT2] })\left(0.03[\text { EVENT3] })=3.0 \times 10^{-8} .\right.\right.\right.
$$




\subsection{RESULTS}

Solving the logic in the fault tree in Figure 1 results in a listing of 39 minimal cutsets, as listed in Appendix A. The quantification of the minimal cutsets resulting from solving the logic in the fault tree in Figure 1 is also represented by the numbers on the far right hand side of Appendix A for each minimal cutset. The total probability of a potential load drop per lift is $1.1 \times 10^{-6}$, which is shown in the upper right hand corner of Appendix A under the column heading "MOD./CS. PROB." This number represents a point estimate value for the probability of potential drop per load test in the south loadout pit $\left(1.1 \times 10^{-6}\right.$ per load test $)$.

\subsection{CONCLUSIONS}

The probability of $1.1 \times 10^{-6}$ per load test is a factor of approximately 25 times smaller than the value used in WHC-SD-WM-SAR-062 (page 3A-3) for cask-MCO drops $\left(2.7 \times 10^{-5}\right.$ per lift). The value of $2.7 \times 10^{-5} \mathrm{per} \mathrm{lift} \mathrm{is} \mathrm{the} \mathrm{midpoint} \mathrm{of} \mathrm{the} \mathrm{frequency} \mathrm{range} \mathrm{for} \mathrm{crane} \mathrm{load} \mathrm{drops}$ described in NUREG-0612. The upper end of the frequency range for crane load drops described in NUREG-0612 is $3.0 \times 10^{-4}$ per lift.

The fault tree model shows the importance of certain components and situations. Since the PLC controls all of the MLS functions, PLC failures are very important. The assumption that the system will be thoroughly tested before the load test occurs reduces the probability of programming errors causing load drops. It is not possible to assign a programming fault-caused probability of load drop without an inordinate amount of analysis, and generic programming error rates do not give any significant insights.

The major contributors to the load drop probability are the random structural failures of the MLS support, the MLS, and the grapple. The failure of the locking pin air cylinder air supply valve coupled with the failure of the locking pin locking pawls is also a major contributor. However, this failure cutset may have an artificially high probability due to the lack of information concerning the reliability of the locking pin locking pawls.

External conditions such as natural phenomena, fires, and floods are not considered in this evaluation. Evaluation of operational conditions in the $\mathrm{K}$ West Basin south loadout pit area gives important insights. Stringent procedural control of the basin crane and cask vehicle movement should be considered to ensure that these types of events do not dominate the probability of a load drop. 


\section{SNF-5569 REV 0}

\subsection{REFERENCES}

DP-1633, 1982, Component Failure-Rate Data with Potential Applicability to a Nuclear Fuel Reprocessing Plant, E.I. du Pont de Nemours \& Co., Savannah River Laboratory, Aiken, South Carolina.

EGG-SSRE-8875, 1990, Generic Component Failure Data Base for Light Water and Liquid Sodium Reactor PRAs, EG\&G Idaho, Incorporated, Idaho Falls, Idaho.

H-1-84031, 1999, Grapple Support Stand South Load-out Pit Plan and Details, Fluor Daniel Hanford, Incorporated, Richland, Washington.

INSPEC (Institution of Electrical Engineers), 1981, Electronic Reliability Data, a Guide to Selected Components, Unwin Brothers Limited, The Gresham Press, Old Woking, Surrey, England.

NAC International, Inc., drawings 101 (Sheets 1, 2, and 3), 201, 210, and 211, NAC International, Inc., Norcross, Georgia.

NPRD-95, 1995, Nonelectronic Parts Reliability Data 1995, Reliability Analysis Center, Rome, New York.

NUREG-0612, 1980, Control of Heavy Loads at Nuclear Power Plants, U.S. Nuclear Regulatory Commission, Washington, D.C.

NUREG/CR-2300, 1982, PRA Procedures Guide, U.S. Nuclear Regulatory Commission, Washington, D.C.

NUREG/CR-4772, 1987, Accident Sequence Evaluation Program Human Reliability Analysis Procedure, Sandia National Laboratories, Albuquerque, New Mexico.

Welker, E. L., and M. Lipow, 1974, "Estimating the Exponential Failure Rate from Data with No Failure Events, from the Proceedings of the 1974 Annual Reliability and Maintainability Symposium, Los Angeles, California.

WHC-EP-0811, 1994, Analysis of Power Loss Data for the 200 Area Tank Farms in Support of K Basin SAR Work, Westinghouse Hanford Company, Richland, Washington.

WHC-SD-MP-SWD-0004, 1993, CAFTA Computer Program Testing and Acceptance Report, Rev. 0-D, Westinghouse Hanford Company, Richland, Washington.

WHC-SD-WM-SAR-062, 1999, K Basins Safety Analysis Report, Rev. 3L, Westinghouse Hanford Company, Richland, Washington.

WSRC-TR-93-262, 1993, Savannah River Site Generic Data Base Development, Westinghouse Savannah River Company, Savannah River Site, Aiken, South Carolina. 
Figure 1. Multi-Canister Overpack Loading System Load Drop in K West South Loadout Pit During Load Test. (Sheet 1 of 12)

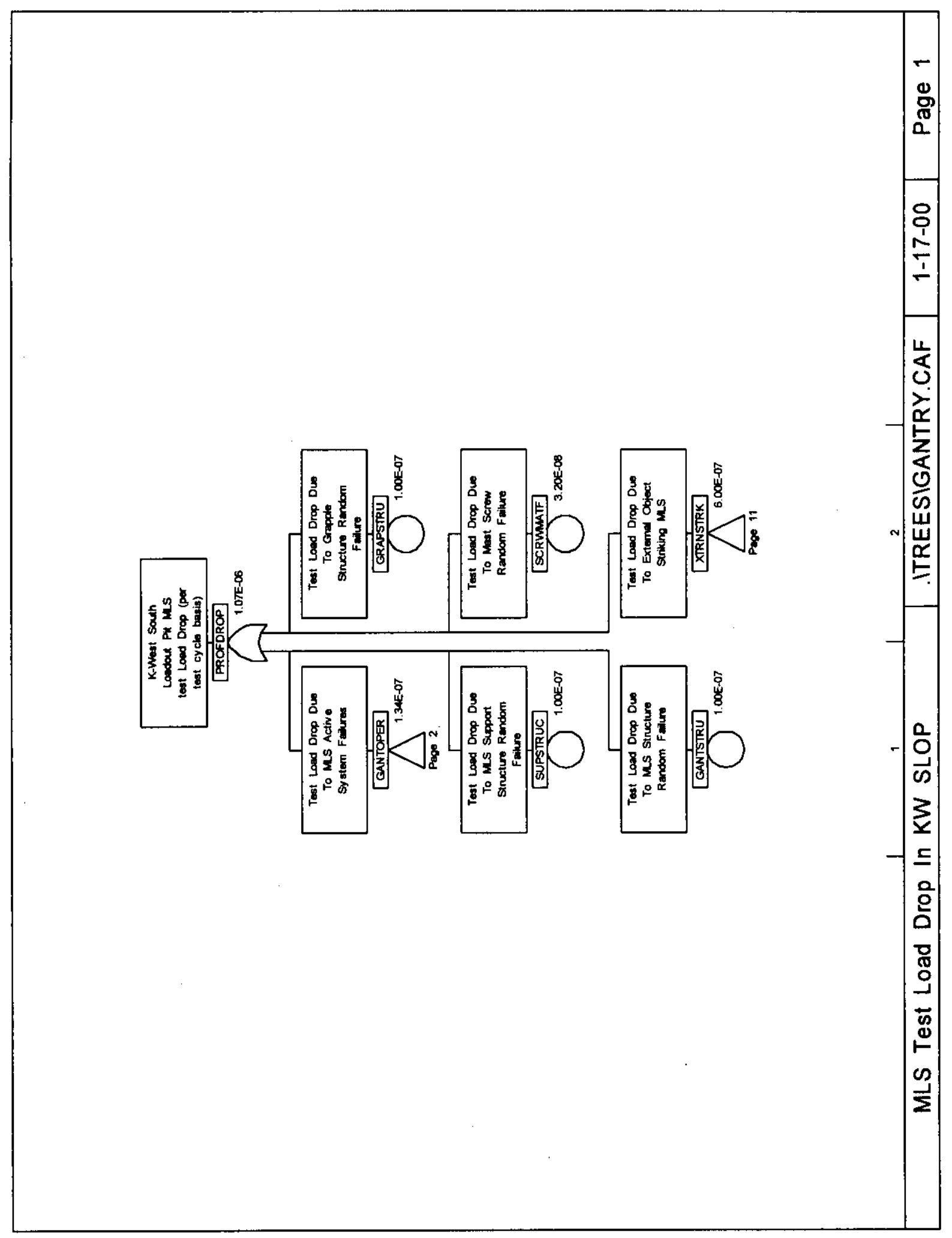


Figure 1. Multi-Canister Overpack Loading System Load Drop in K West South Loadout Pit During Load Test. (Sheet 2 of 12)

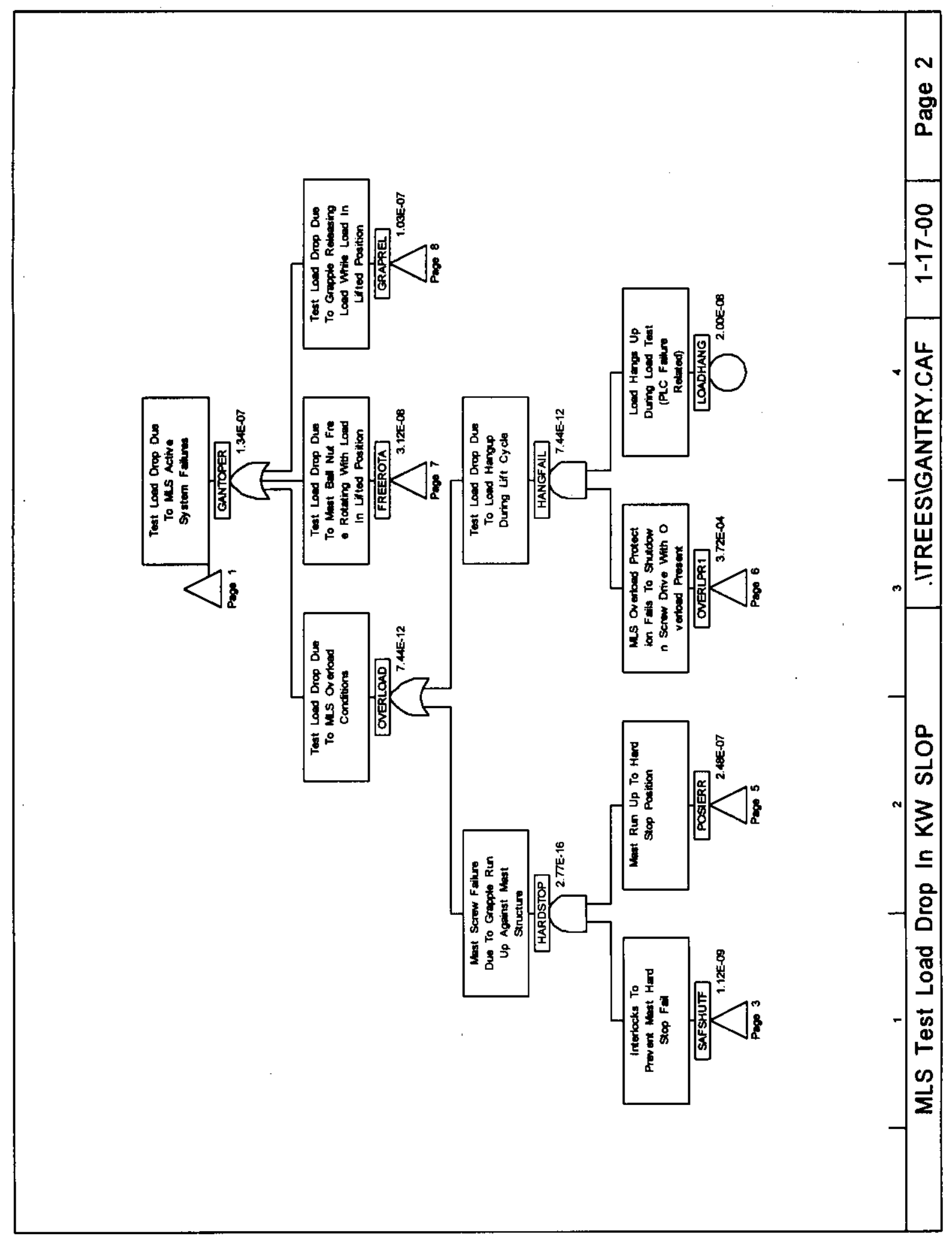


Figure 1. Multi-Canister Overpack Loading System Load Drop in K West South Loadout Pit During Load Test. (Sheet 3 of 12)

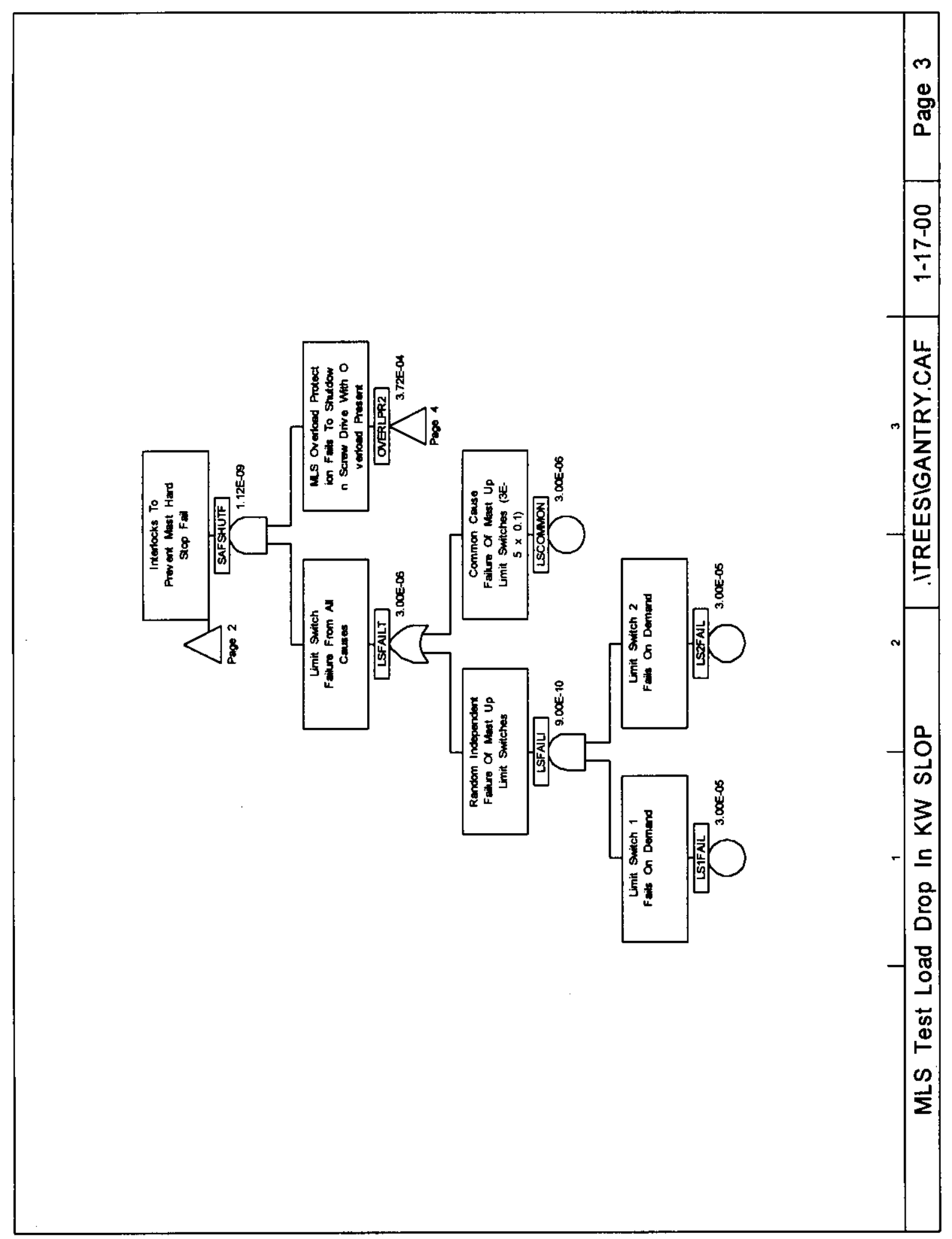


Figure 1. Multi-Canister Overpack Loading System Load Drop in K West South Loadout Pit During Load Test. (Sheet 4 of 12)

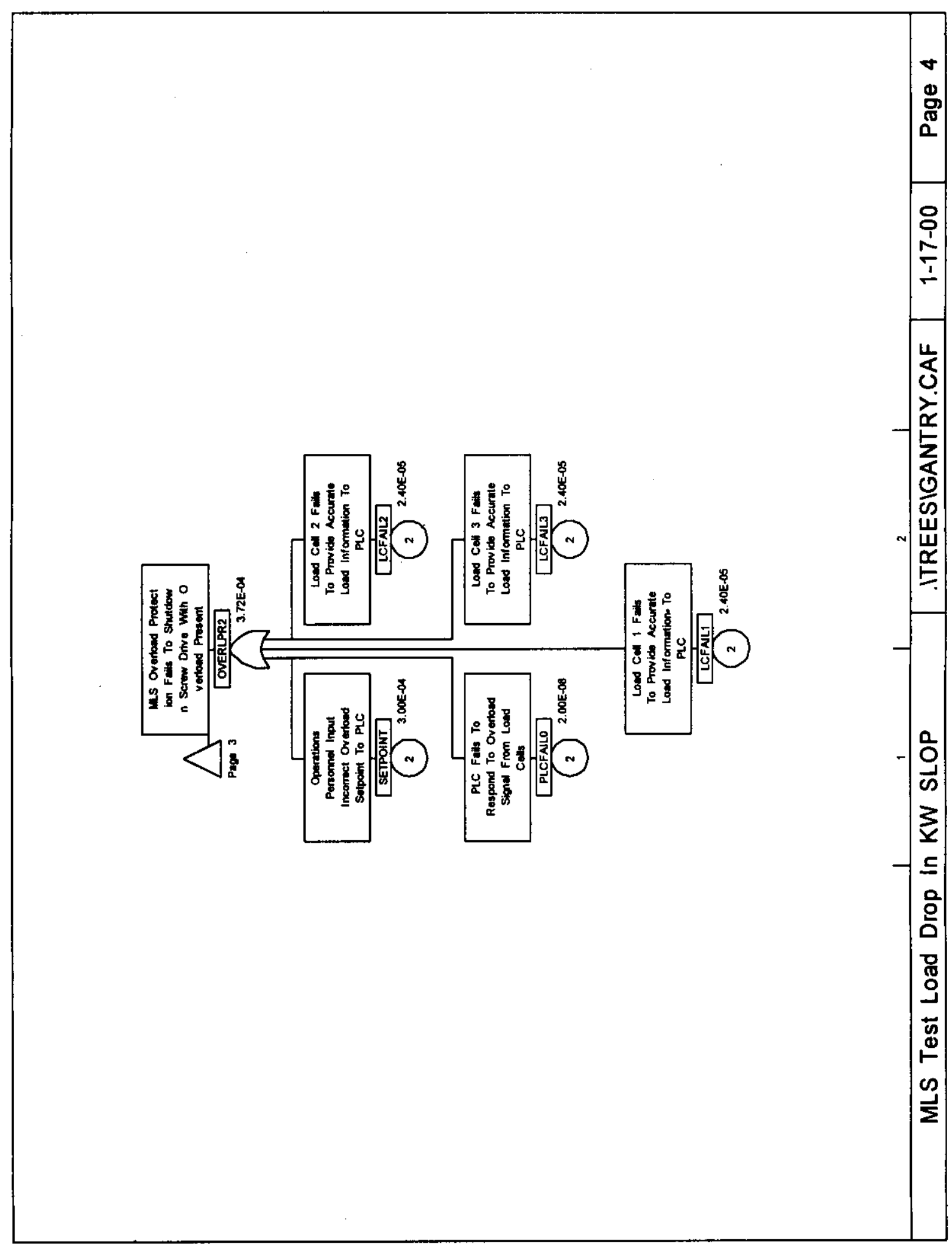


Figure 1. Multi-Canister Overpack Loading System Load Drop in K West South Loadout Pit During Load Test. (Sheet 5 of 12)

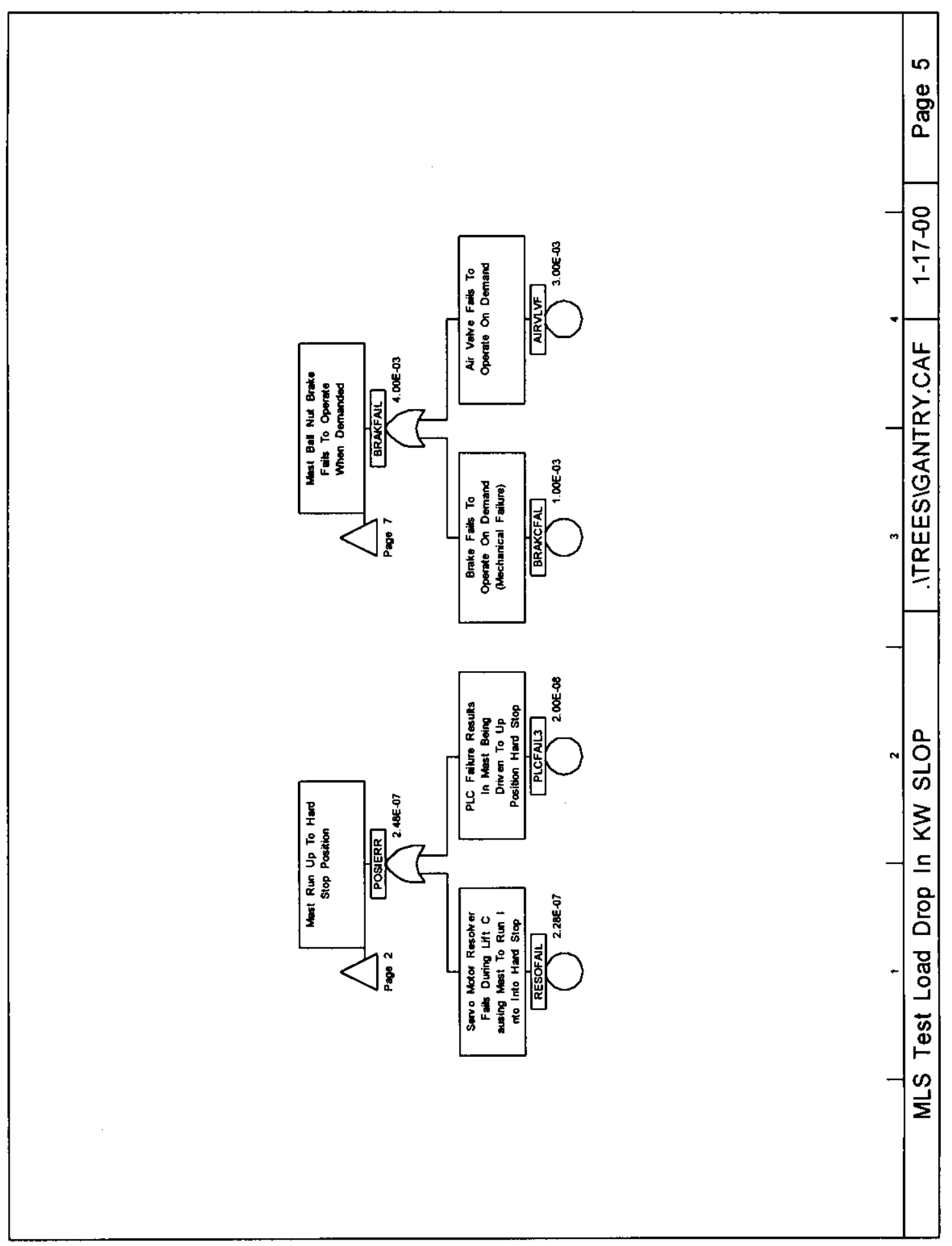


Figure 1. Multi-Canister Overpack Loading System Load Drop in K West South Loadout Pit During Load Test. (Sheet 6 of 12)

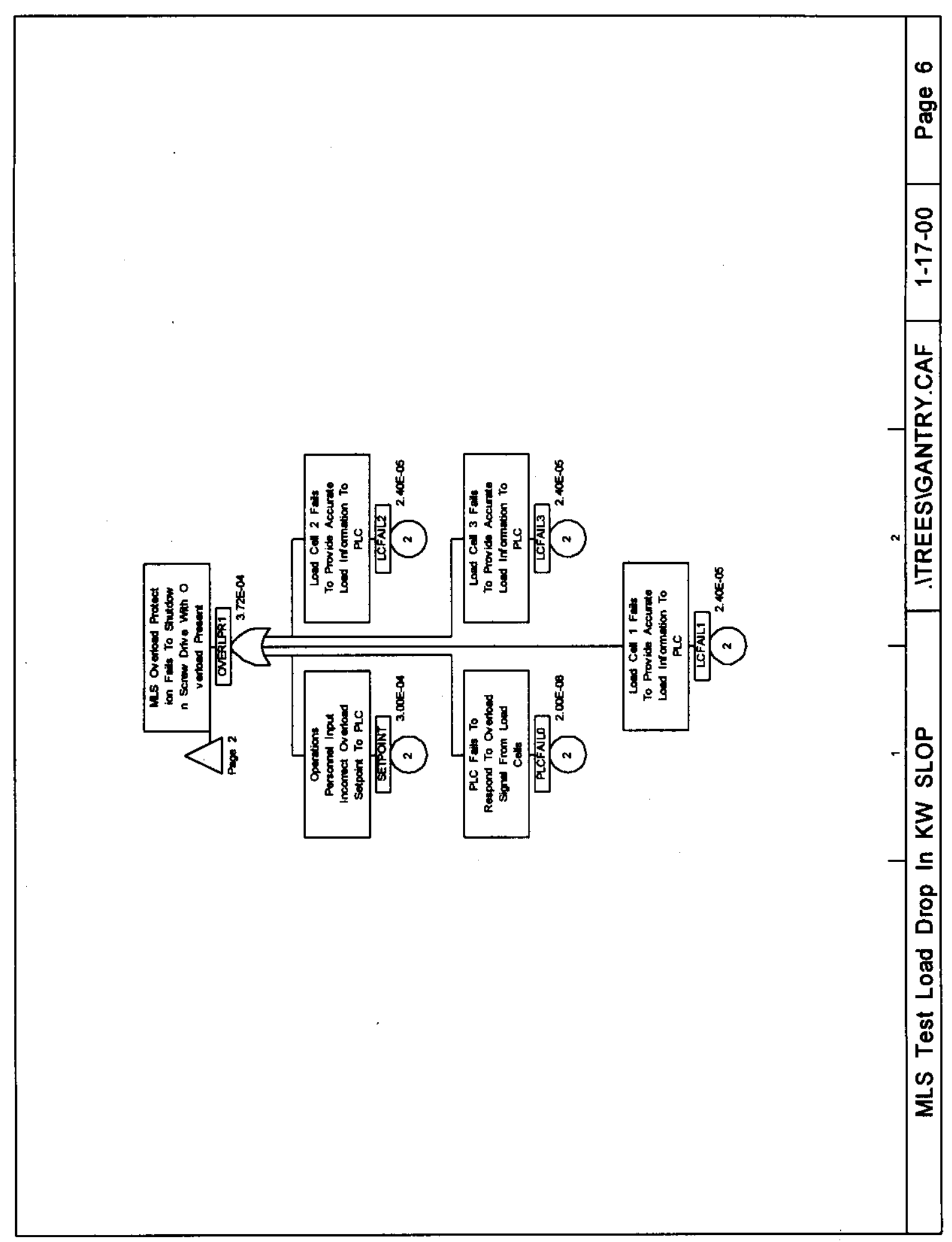


Figure 1. Multi-Canister Overpack Loading System Load Drop in K West South Loadout Pit During Load Test. (Sheet 7 of 12)

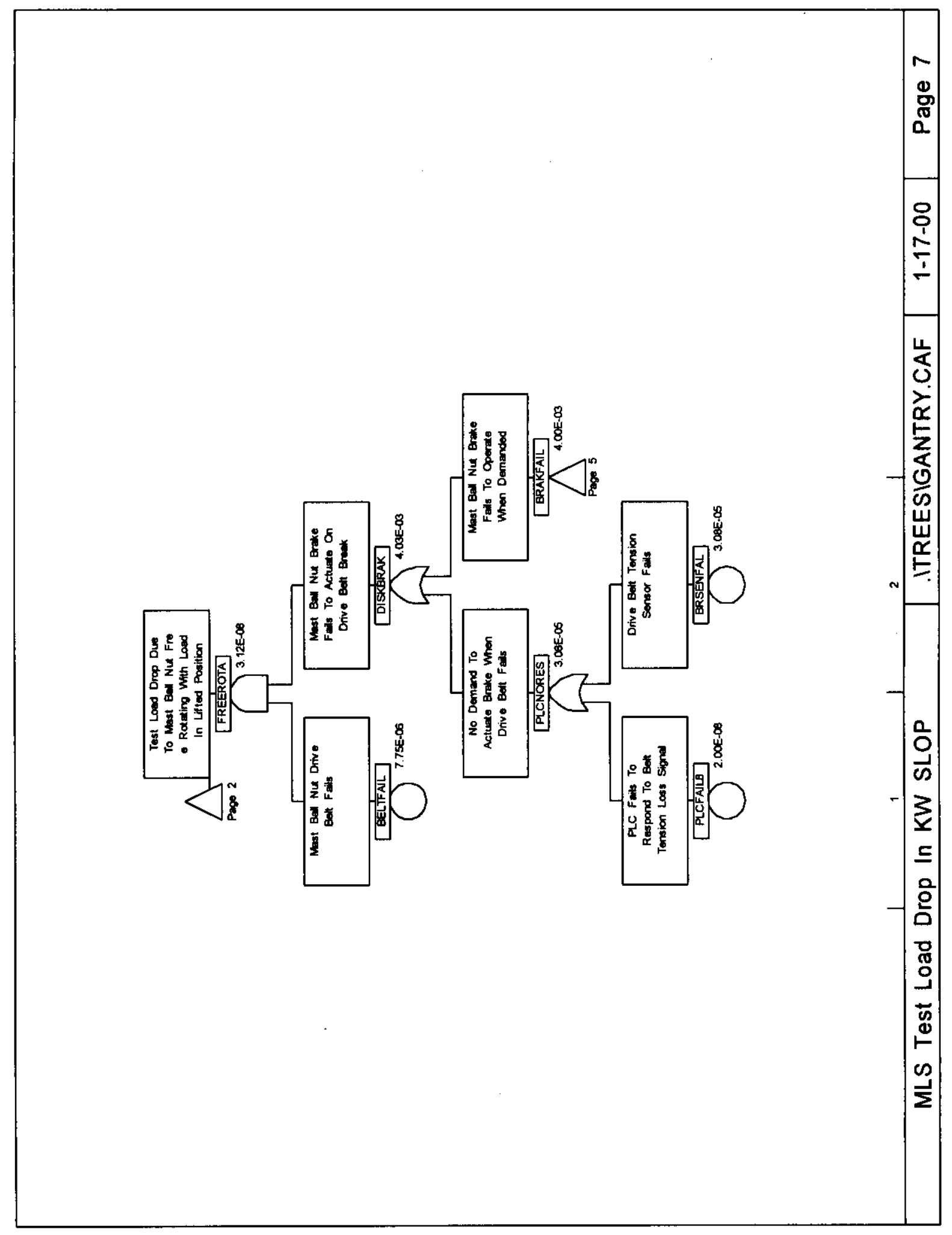


Figure 1. Multi-Canister Overpack Loading System Load Drop in K West South Loadout Pit During Load Test. (Sheet 8 of 12)

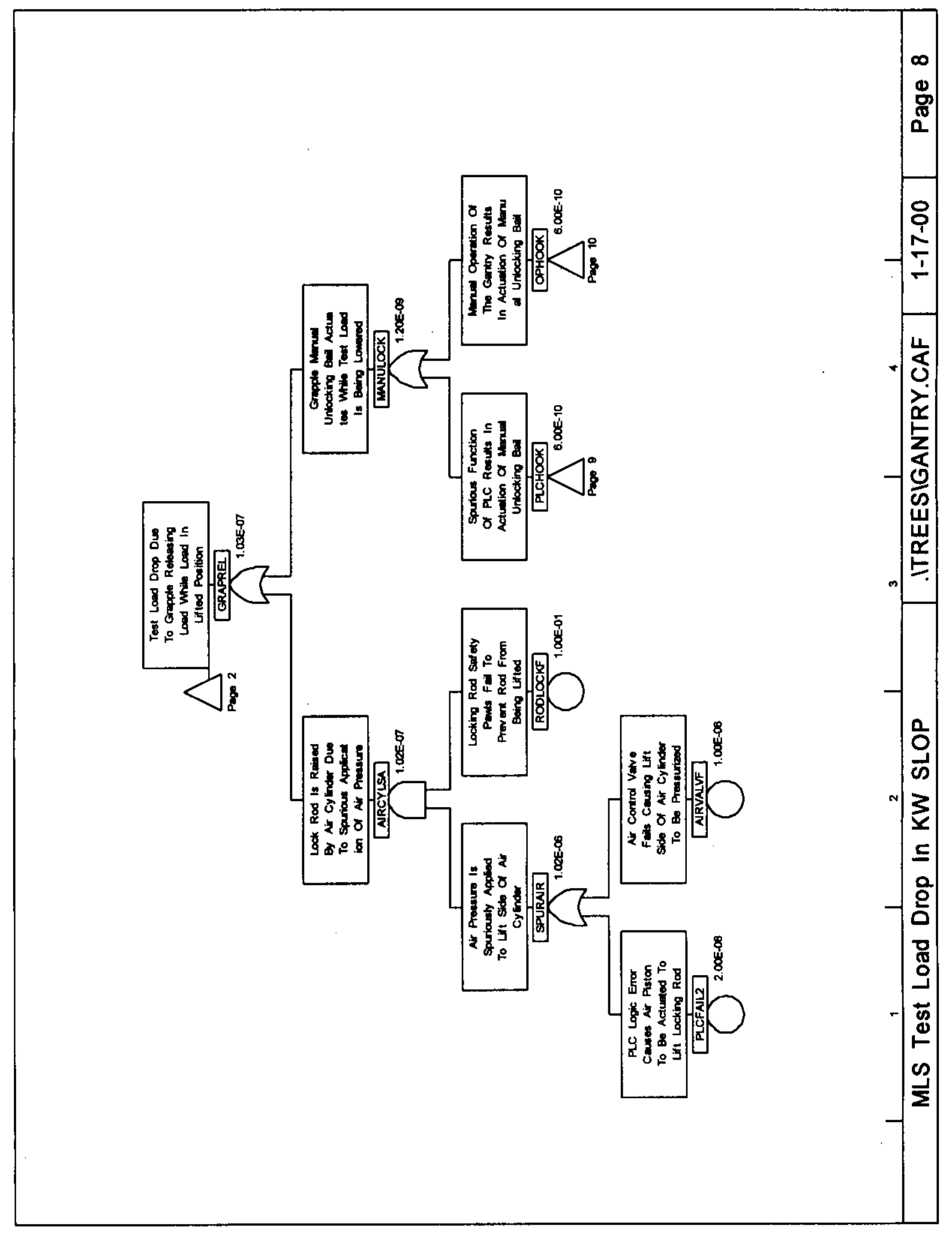


Figure 1. Multi-Canister Overpack Loading System Load Drop in K West South Loadout Pit During Load Test. (Sheet 9 of 12)

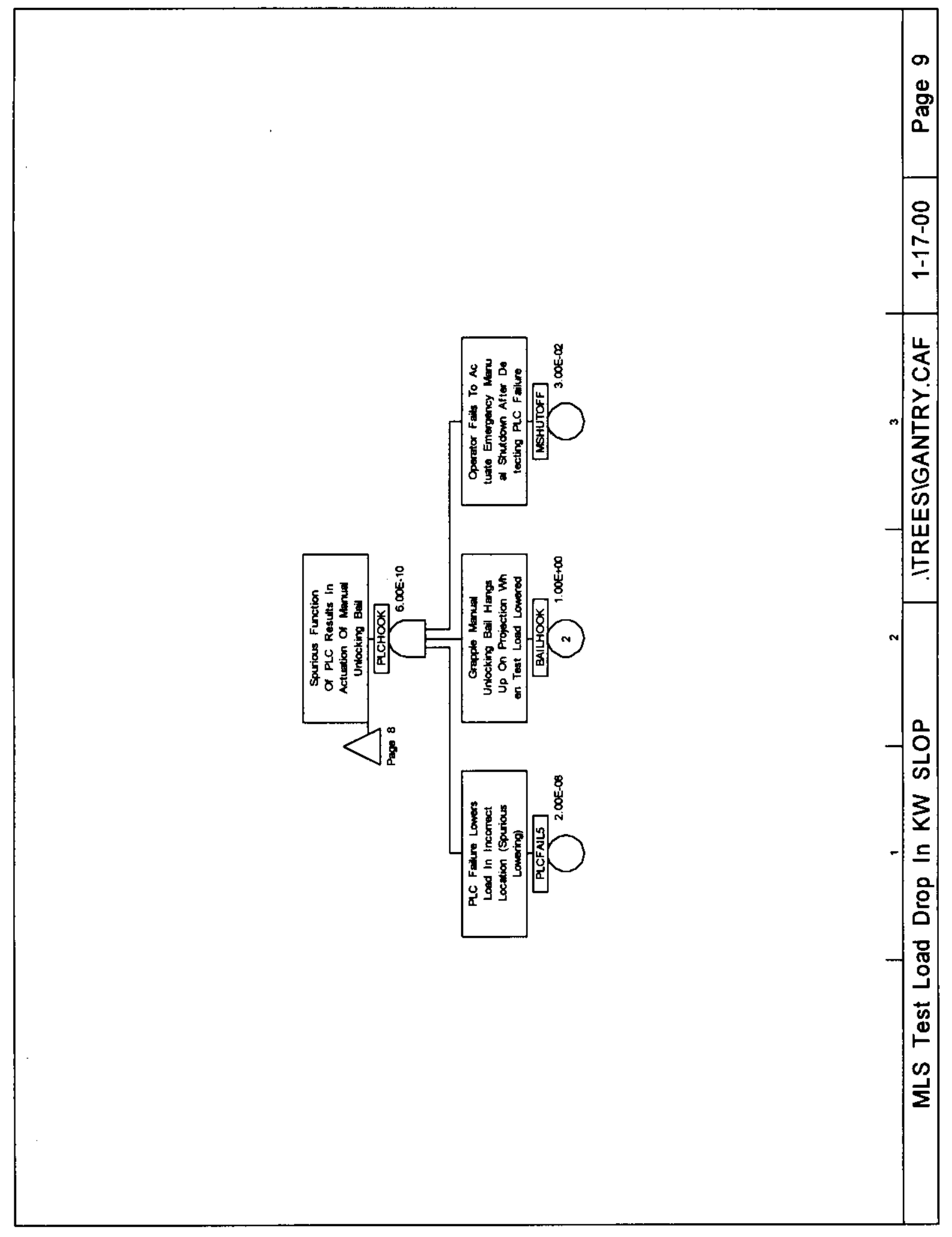


Figure 1. Multi-Canister Overpack Loading System Load Drop in K West South Loadout Pit During Load Test. (Sheet 10 of 12)

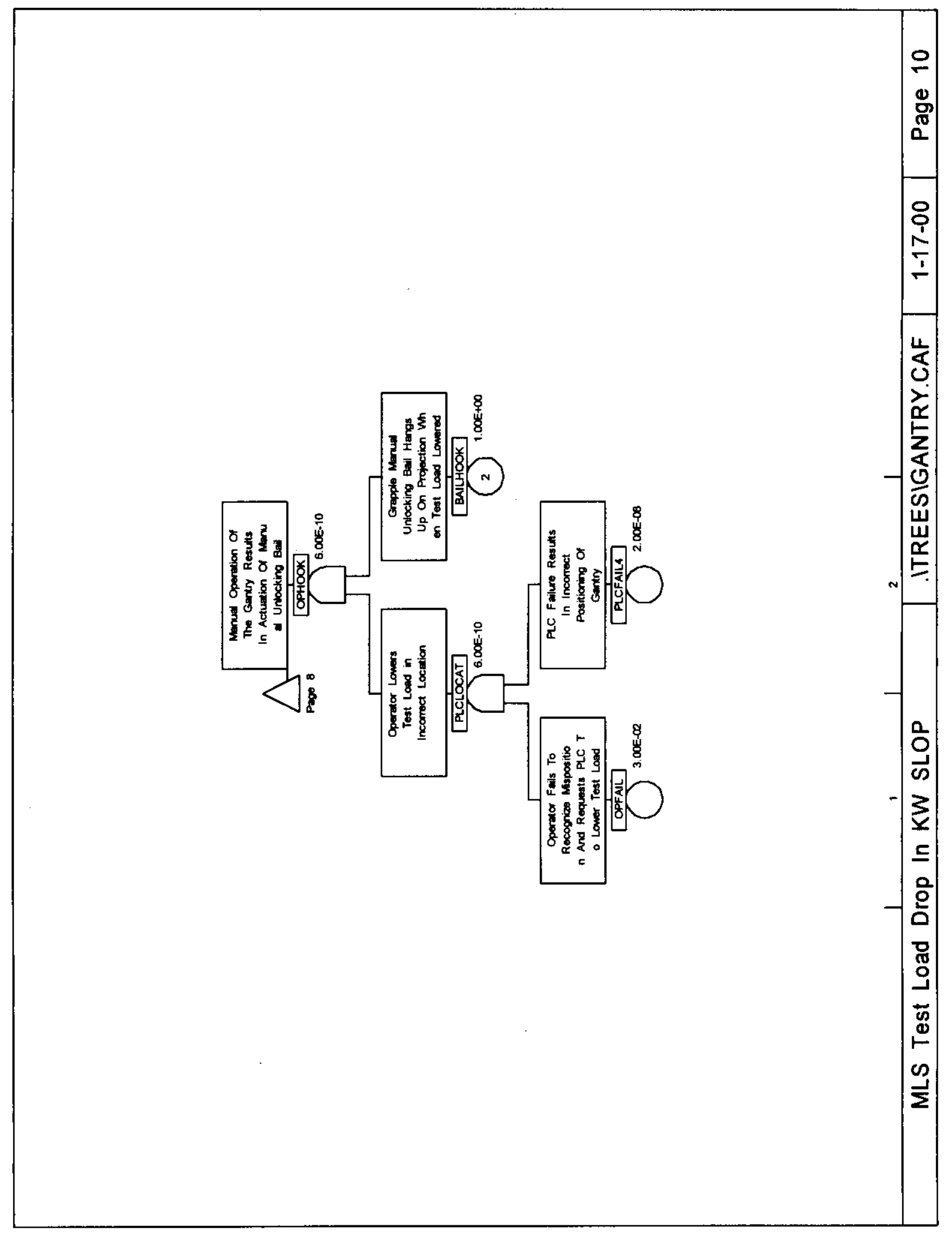


Figure 1. Multi-Canister Overpack Loading System Load Drop in K West South Loadout Pit During Load Test. (Sheet 11 of 12)

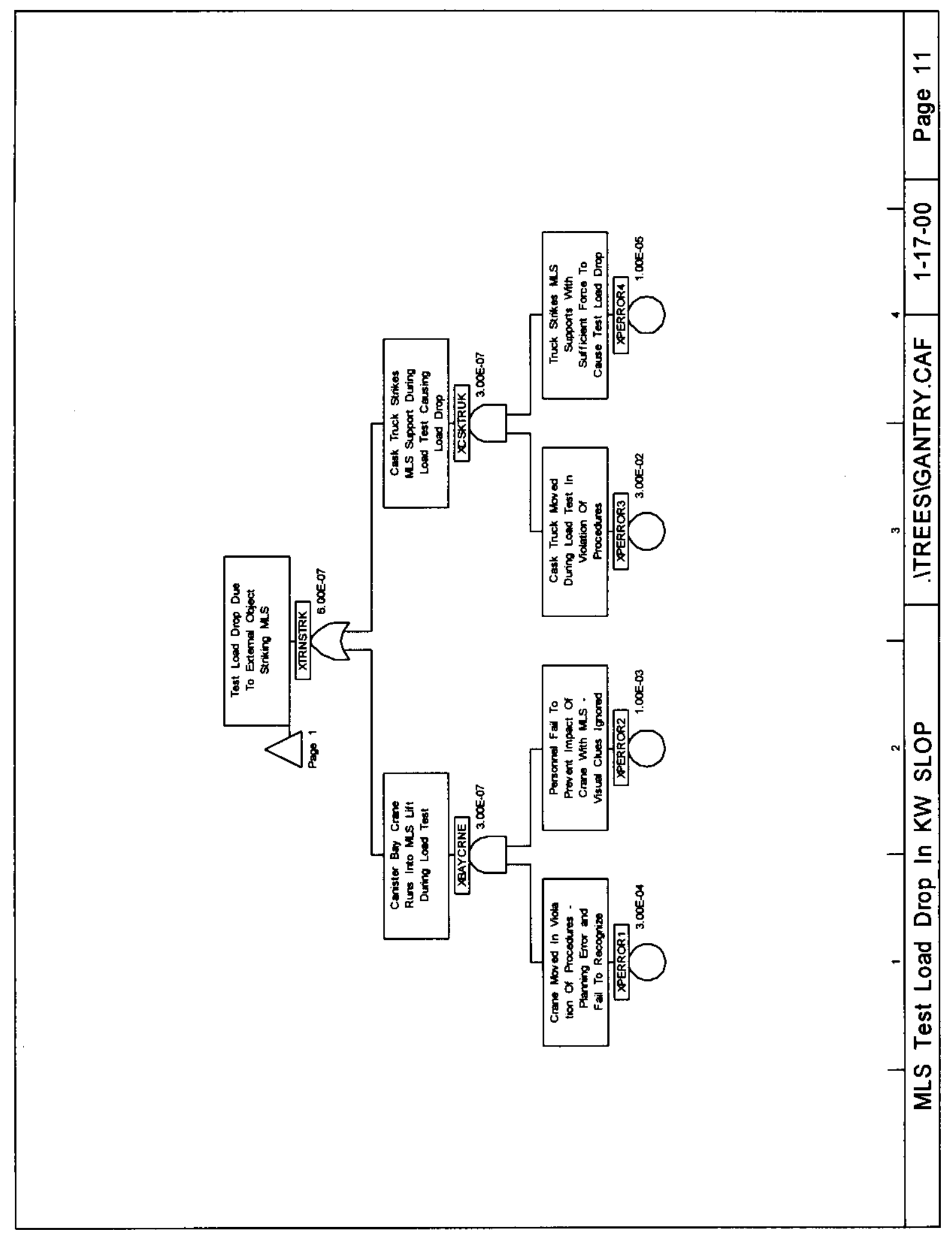


Figure 1. Multi-Canister Overpack Loading System Load Drop in K West South Loadout Pit During Load Test. (Sheet 12 of 12)

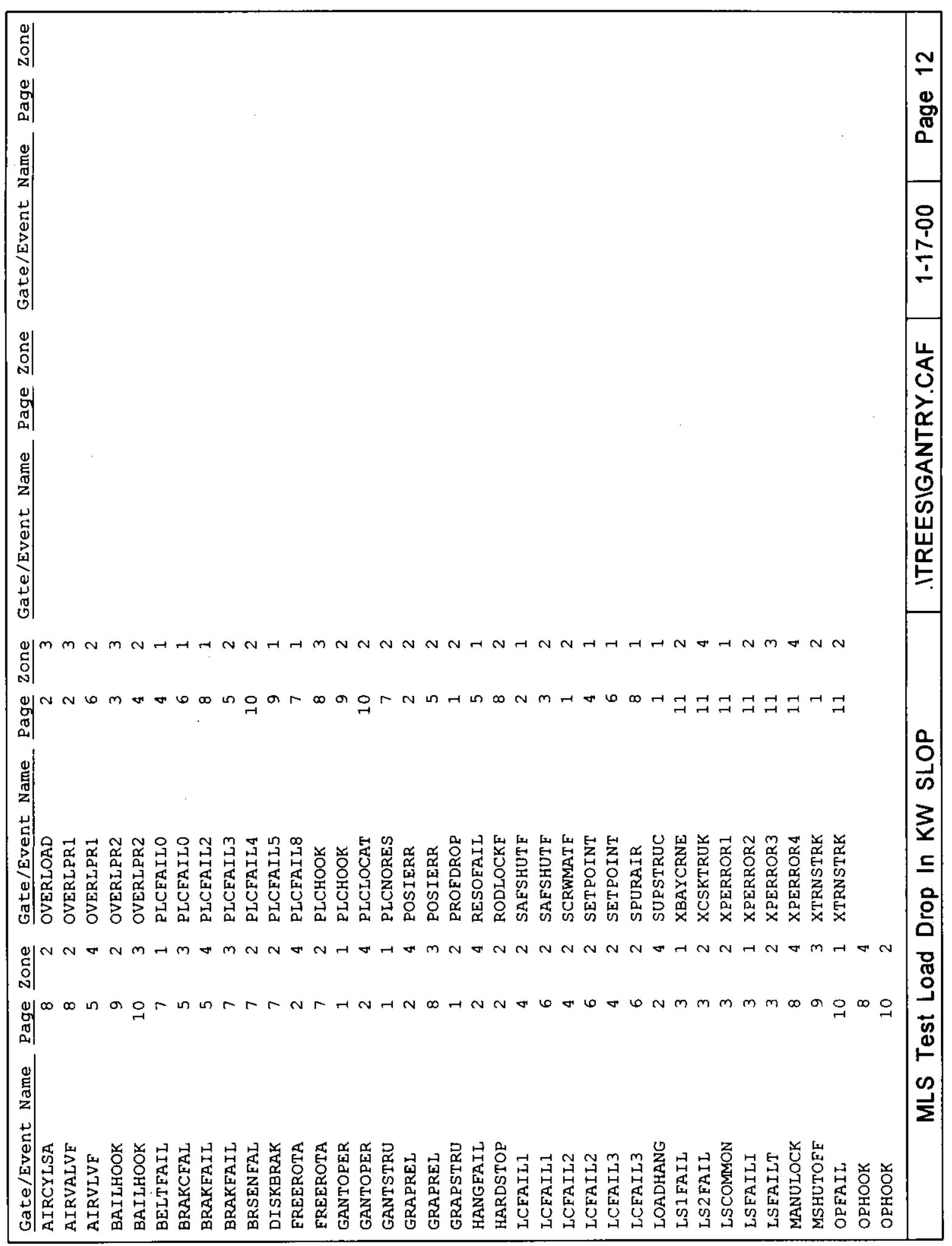


SNF-5569 REV 0

\section{APPENDIX A \\ CUTSET REPORT}


SNF-5569 REV 0

This page intentionally left blank. 


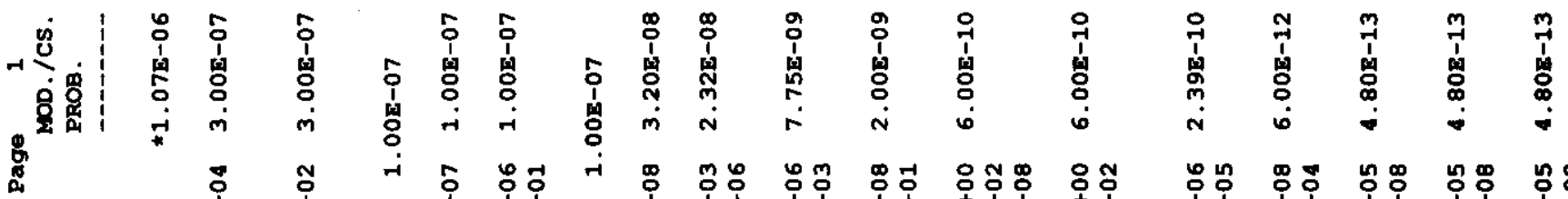

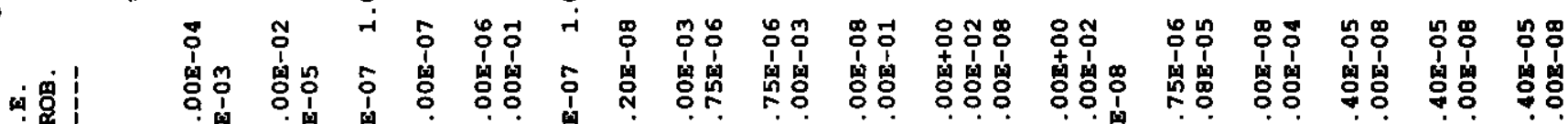
m

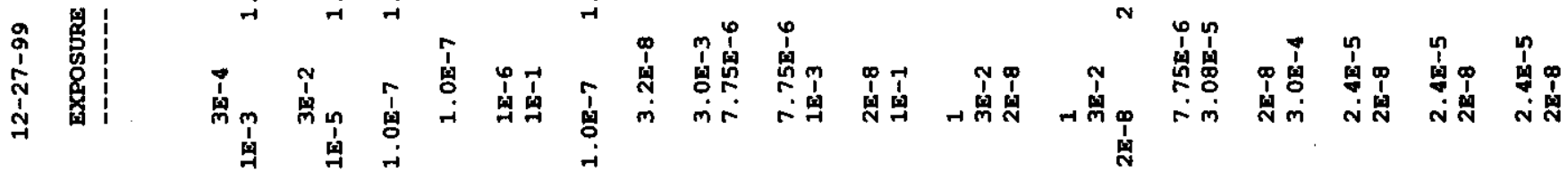
国

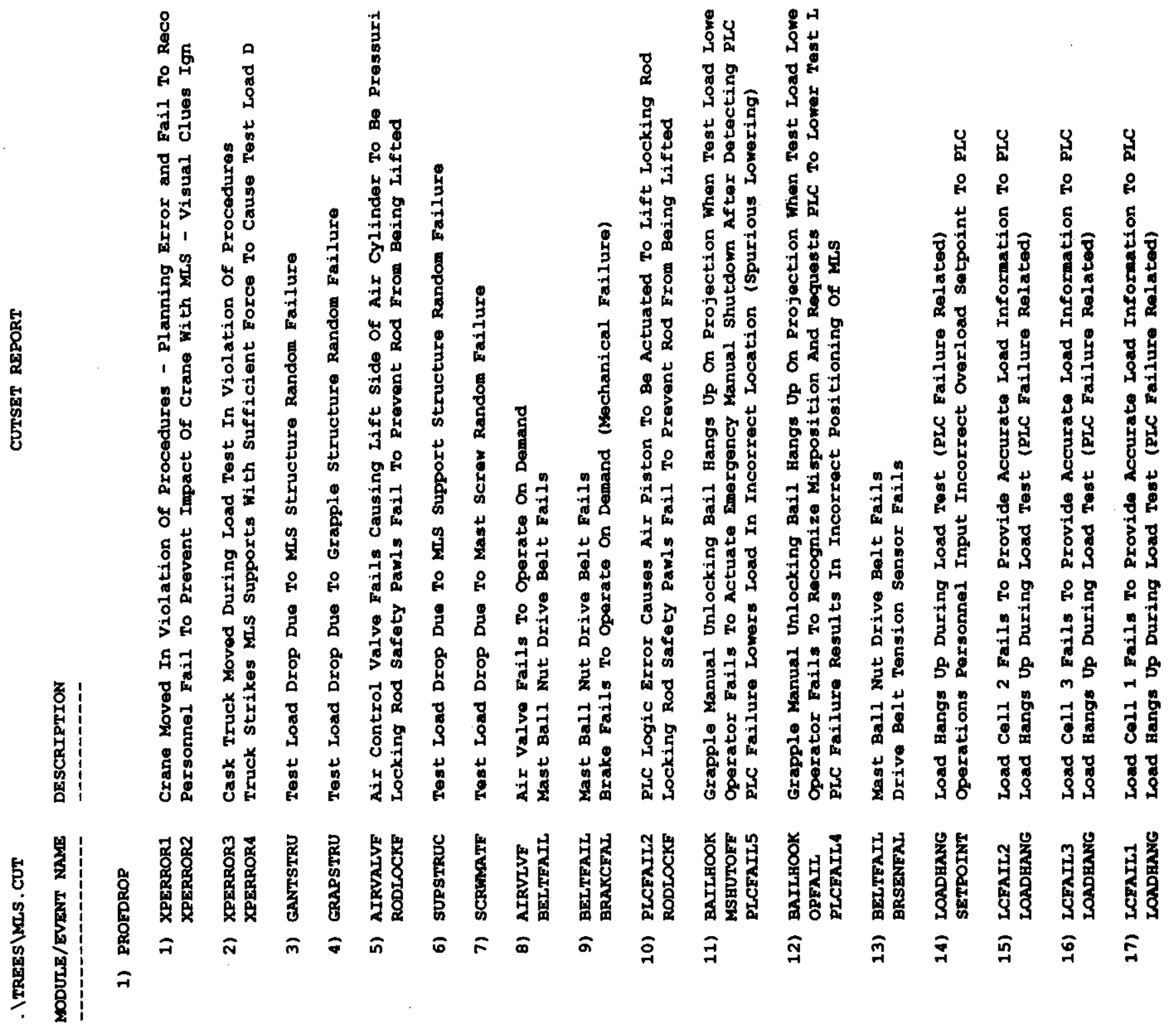




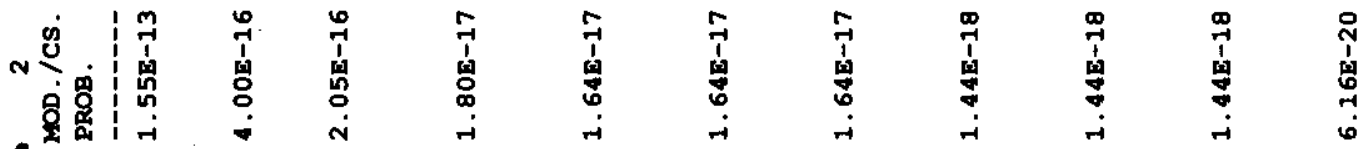
g 蠆

: : $:$

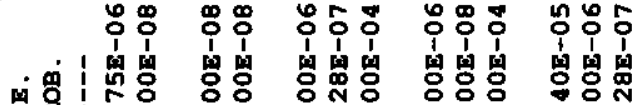

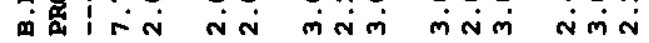

눙ํㅇ

圆产龱

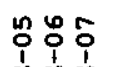

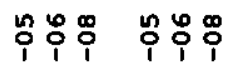

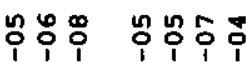

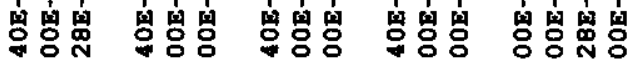

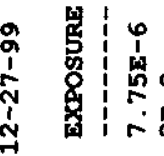

ì

$\infty-$

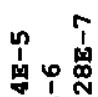

NMN

imin

तini

im

Nin

in $\dot{\text { i }} \dot{m}$

!

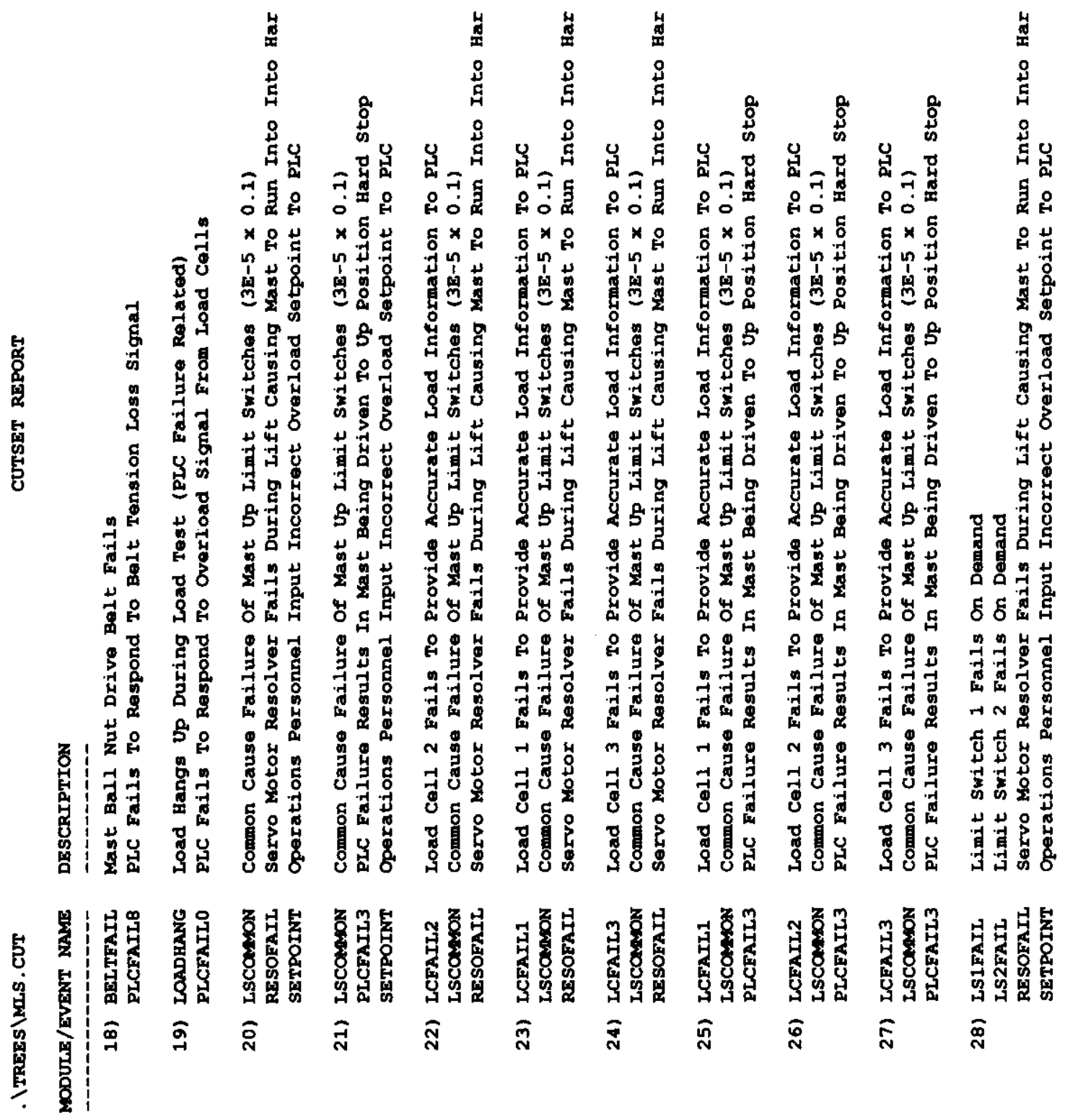




\begin{tabular}{|c|c|c|c|c|c|c|c|c|c|c|c|}
\hline छ் . & 衤 & 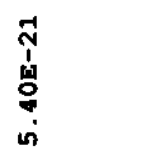 & 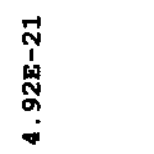 & 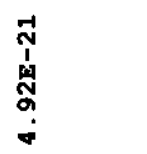 & \begin{tabular}{c}
\multirow{1}{1}{} \\
$\vdots$ \\
\multirow{2}{*}{} \\
$\vdots$
\end{tabular} & 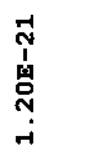 & 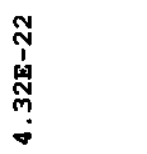 & 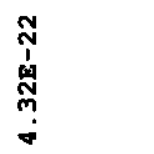 & 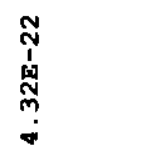 & 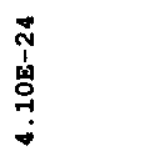 & $\begin{array}{l}\stackrel{n}{N} \\
\vdots \\
\dot{0} \\
0 \\
\dot{n} \\
\dot{m}\end{array}$ \\
\hline 实 & 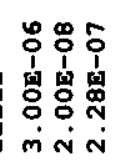 & 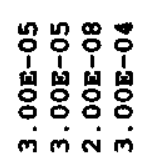 & 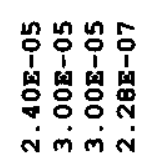 & 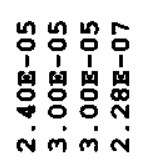 & 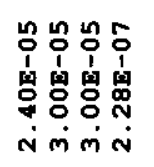 & 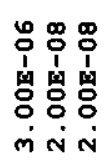 & 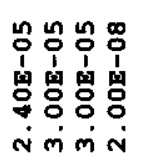 & 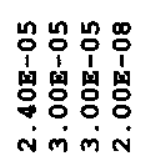 & 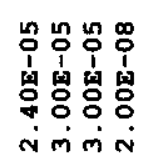 & 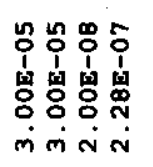 & 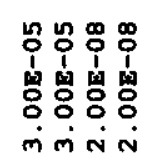 \\
\hline 8 & 离 & 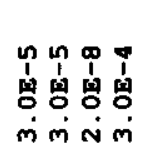 & 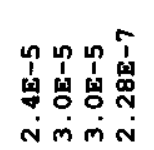 & 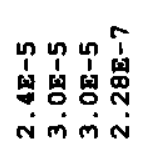 & 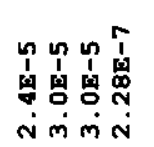 & 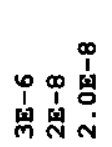 & 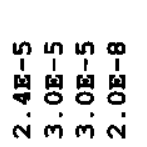 & 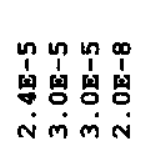 & 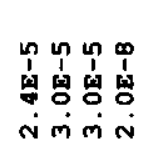 & 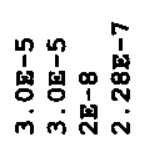 & 吊员 \\
\hline
\end{tabular}

罢

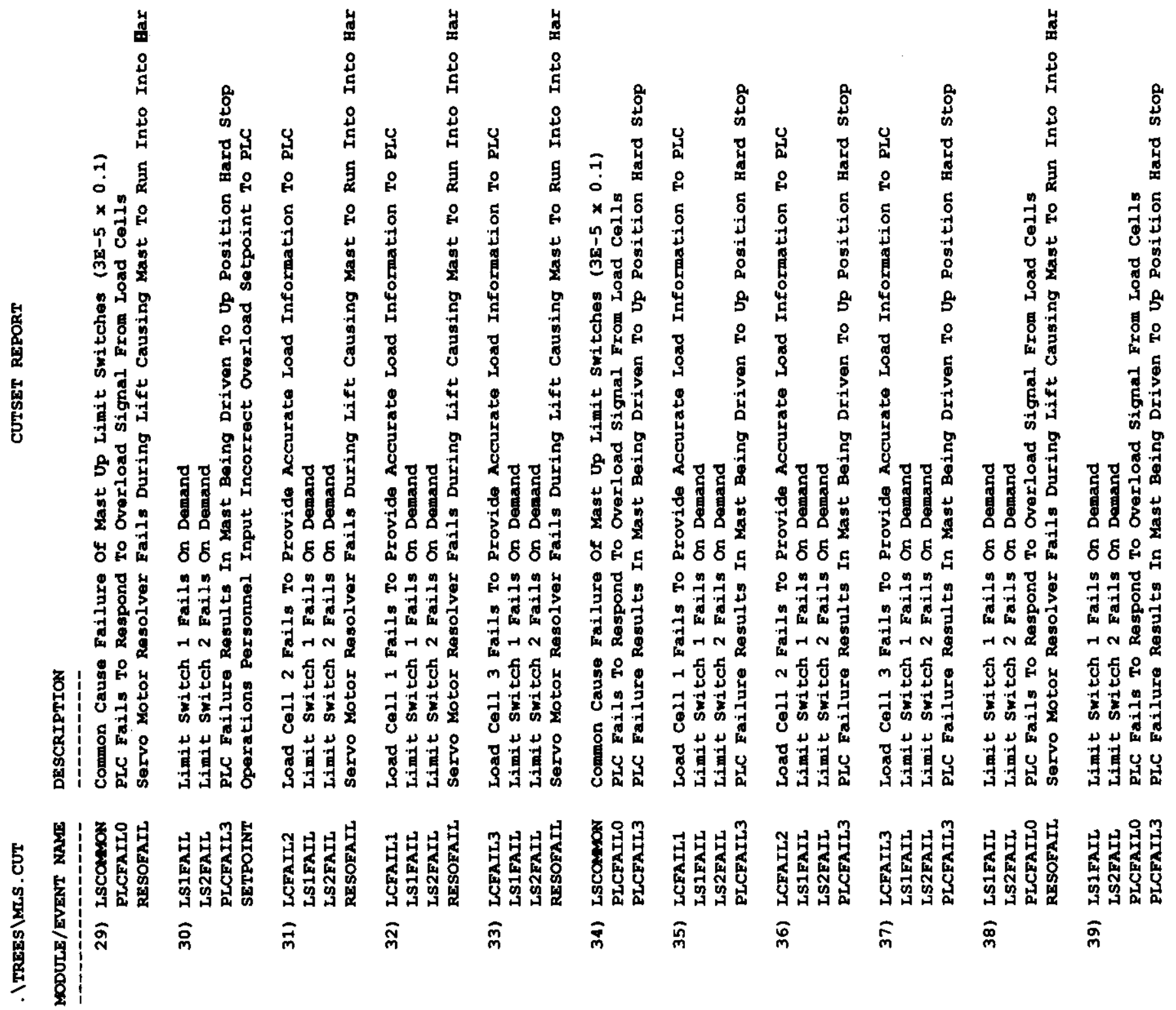




\section{SNF-5569 REV 0}

This page intentionally left blank.

snf-5569.doc 
SNF-5569 REV 0

APPENDIX B

BASIC EVENT DATA

snf-5569.doc

B-1

January 17,2000 
SNF-5569 REV 0

This page intentionally left blank. 

न

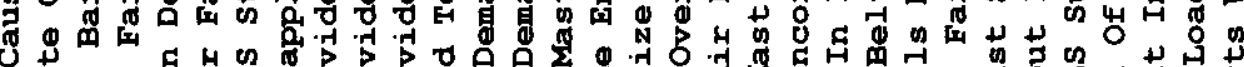
on

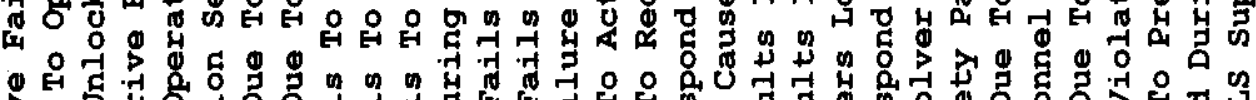

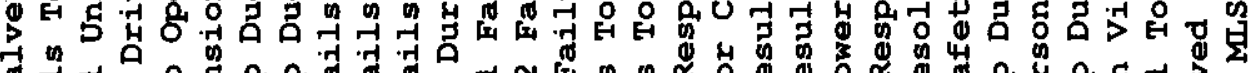

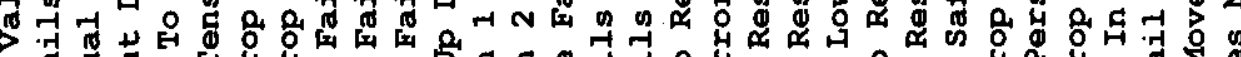

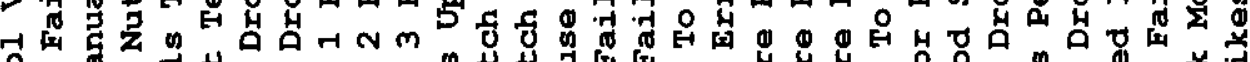
过

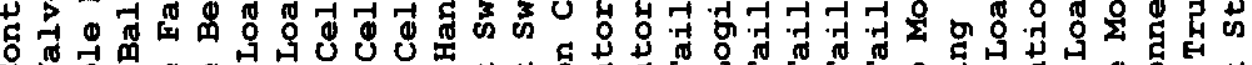

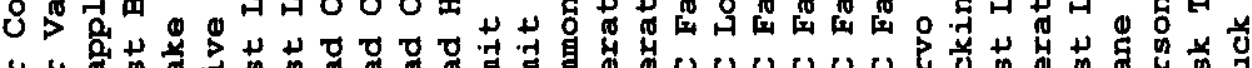

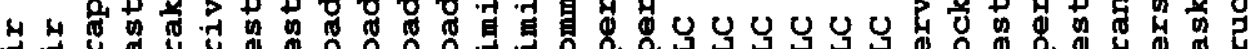

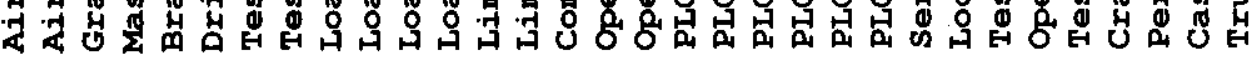
ம i

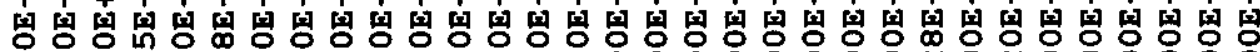

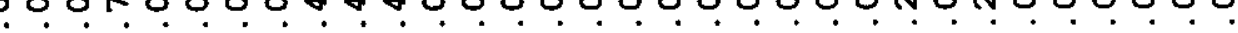

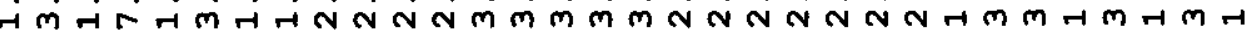

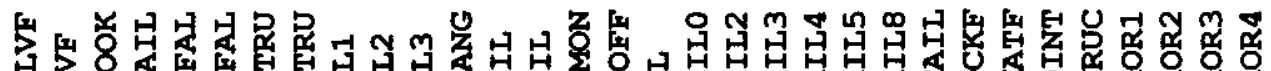

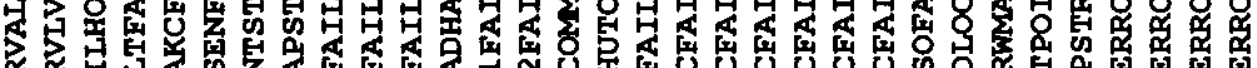

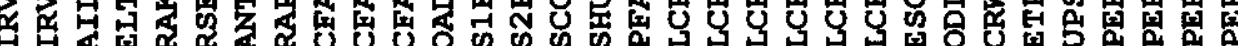

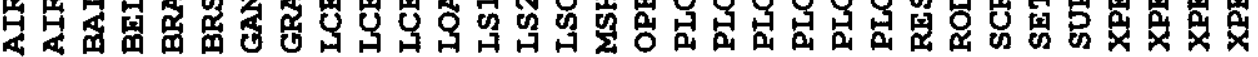

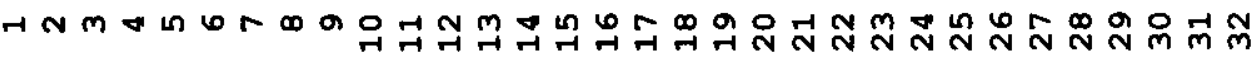


SNF-5569 REV 0

This page intentionally left blank. 
SNF-5569 REV 0

APPENDIX C

\section{PEER REVIEW CHECKLISTS}




\section{SNF-5569 REV 0}

This page intentionally left blank. 


\section{PEER REVIEW GHECKLIST}

Document Title: $\quad$ SNF-5569, Probability of Potential Multi-Canister Overpack Loading System Drop of Proof Load in the K West Basin South Loadout Pit

.Document Author: Milt Shultz

Document Date:

Scope of Review:

\section{December 1999}

Yes No NA

[] [] \]

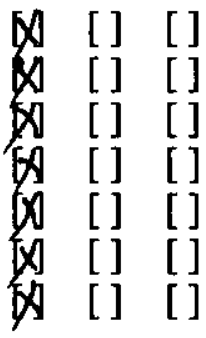

如 [ ] [ ]

冈 [ [ ] [ ]

如 [ ] [ ]

优 [ [ ] [ ]

[] []

的 [ ] [ ]

[ [ ] [ ]

[ [ ] [ ]

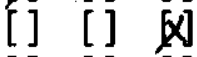

[] [] 风]

(W
Previous reviews complete and cover analysis, up to scope of this review, with no gaps.

Problem completely defined.

Accident scenarios developed in a clear and logical manner.

Necessary assumptions explicitly stated and supported.

Computer codes and data files documented.

Data used in calculations explicitly stated in document.

Data checked for consistency with original source information as applicable.

Mathematical derivations checked including dimensional consistency of results.

Models appropriate and used within range of validity or use outside range of established validity justified.

Hand calculations checked for errors. Spreadsheet results should be treated exactly the same as hand calculations.

Software input correct and consistent with document reviewed.

Software output consistent with input and with results reported in document reviewed.

Limits/criteria/guidelines applied to analysis results are appropriate and referenced. Limits/criteria/guidelines checked against references.

Safety margins consistent with good engineering practices.

Conclusions consistent with analytical results and applicable limits.

Results and conclusions address all points required in the problem statement. Format consistent with appropriate NRC Regulatory Guide or other standards Review calculations, comments, and/or notes are attached.

\section{Document approved.}

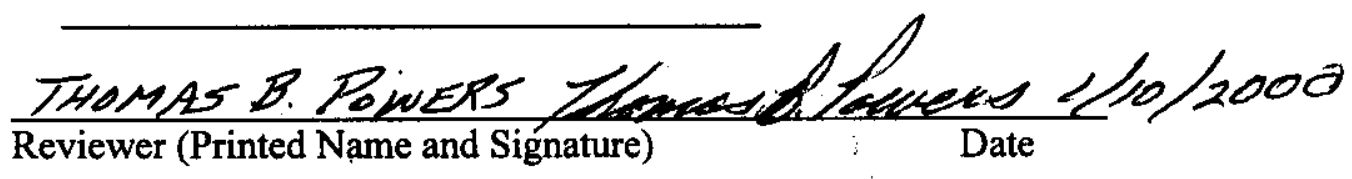




\section{CHECKLIST FOR TECHNICAL PEER REVIEW}

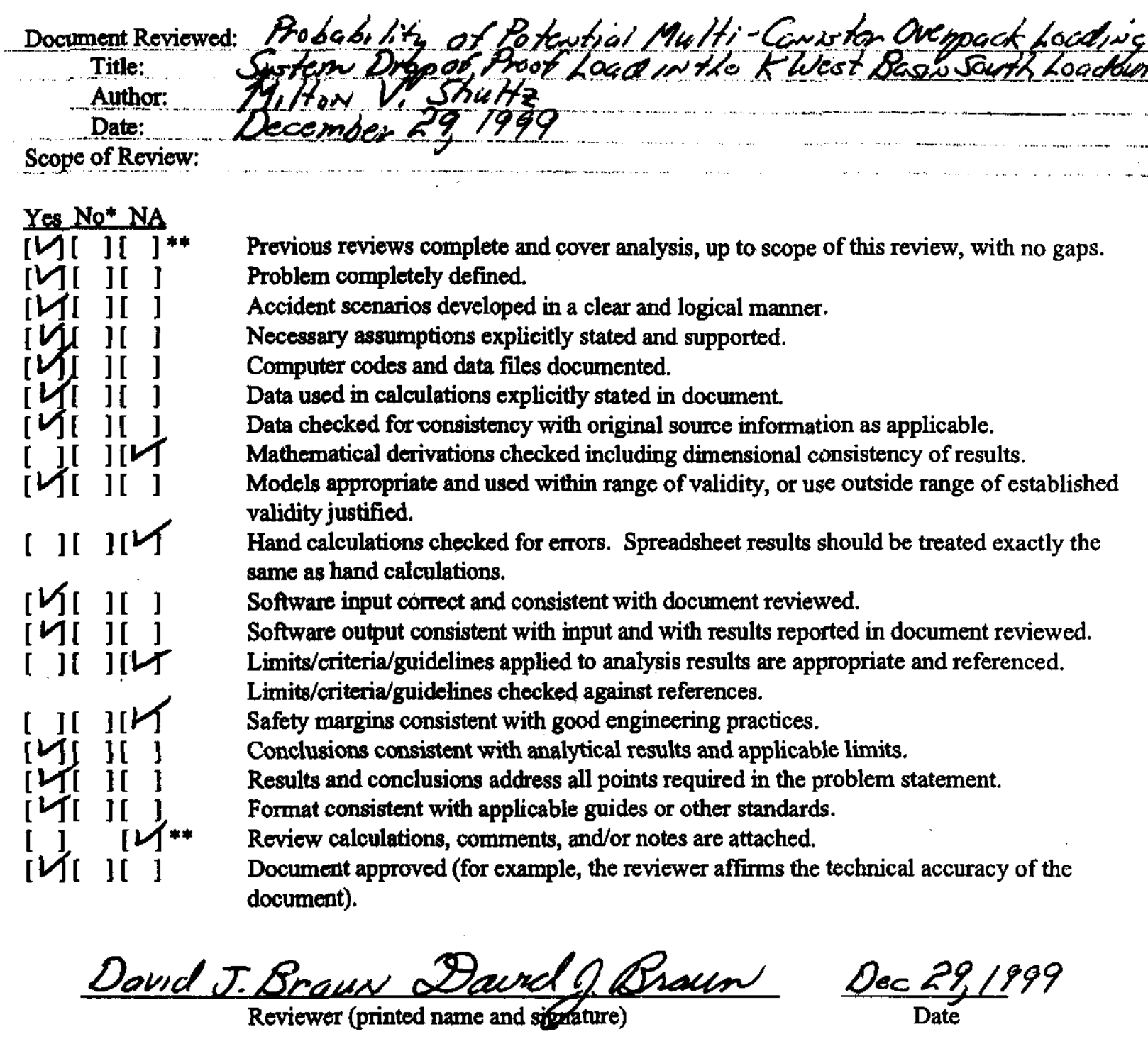

" All "no" responses must be explained below or on an additional sheet.

** Any calculations, comments, or notes generated as part of this review should be signed, dated, and attached to this checklist. The material should be labeled and recorded in such a manner as to be intelligible to a technically qualified third party. 


\section{DISTRIBUTION SHEET}

\begin{tabular}{|c|c|c|c|c|c|}
\hline \multirow[t]{2}{*}{$\begin{array}{l}\text { To } \\
\text { Distribution }\end{array}$} & \multirow{2}{*}{\multicolumn{3}{|c|}{$\begin{array}{l}\text { From } \\
\text { Fluor Federal Services }\end{array}$}} & \multicolumn{2}{|l|}{ Page 1 of 1} \\
\hline & & & & \multicolumn{2}{|c|}{ Date January 10,2000} \\
\hline \multicolumn{4}{|c|}{ Project Title/Work Order SNF-5569, Rev. 0} & \multicolumn{2}{|c|}{ EDT No. 622288} \\
\hline \multicolumn{4}{|c|}{$\begin{array}{l}\text { Probability of Potential Multicanister Overpack } \\
\text { Loading Systems Drop of Proof Load in the } K \text { West } \\
\text { Basin South Loadout Pit }\end{array}$} & \multicolumn{2}{|c|}{ ECN No. N/A } \\
\hline Name & MSIN & $\begin{array}{l}\text { Text } \\
\text { With All } \\
\text { Attach. }\end{array}$ & Text Only & $\begin{array}{l}\text { Attach./ } \\
\text { Appendix } \\
\text { Only }\end{array}$ & $\begin{array}{c}\text { EDT/ECN } \\
\text { Only }\end{array}$ \\
\hline
\end{tabular}

C. J. Alderman

K. E. Ardes

R. L. Boylestonn

J. R. Ellis (5)

R. L. Garrett

K. D. Gibson

B. S. Lew

T. B. Powers

L. A. Rodgers

M. V. Shultz

J. L. Weamer

R. H. Webb

SNF Project Files

Central Files (2)

$\begin{array}{ll}\text { R3-11 } & \text { X } \\ \text { X3-85 } & \text { X } \\ \text { R3-26 } & \text { X } \\ \text { R3-26 } & \text { X } \\ \text { R3-26 } & \text { X } \\ \text { R3-26 } & \text { X } \\ \text { X3-79 } & \text { X } \\ \text { R3-26 } & \text { X } \\ \text { X3-85 } & \text { X } \\ \text { B4-47 } & \text { X } \\ \text { X3-85 } & \text { X } \\ \text { R3-85 } & \text { X } \\ \text { R3-11 } & \text { X } \\ \text { B1-07 } & \text { X }\end{array}$

